\title{
Role of Cannabinoid Type 1 Receptors in Locomotor Activity and Striatal Signaling in Response to Psychostimulants
}

\author{
Anne-Gaëlle Corbillé, ${ }^{1,2,3 *}$ Emmanuel Valjent, ${ }^{1,2,3 *}$ Giovanni Marsicano, ${ }^{4}$ Catherine Ledent, ${ }^{5}$ Beat Lutz, ${ }^{4}$ Denis Hervé, ${ }^{1,2,3}$ \\ and Jean-Antoine Girault ${ }^{1,2,3}$ \\ ${ }^{1}$ Inserm, U839, F-75005 Paris, France, ${ }^{2}$ Université Pierre et Marie Curie (UPMC-Paris 6), F-75005 Paris, France, ${ }^{3}$ Institut du Fer a Moulin, F-75005 Paris, \\ France, ${ }^{4}$ Department of Physiological Chemistry, Johannes Gutenberg University, D-55099 Mainz, Germany, and ${ }^{5}$ Institut de Recherches en Biologie \\ Humaine et Moléculaire, Université de Bruxelles, Campus Erasme, B-1070 Brussels, Belgium
}

\begin{abstract}
A single administration of cocaine or D-amphetamine produces acute hyperlocomotion and long-lasting increased sensitivity to subsequent injections. This locomotor sensitization reveals the powerful ability of psychostimulants to induce brain plasticity and may participate in the alterations that underlie addiction. We investigated the role of cannabinoid receptor type 1 (CB1-R) in the effects of a single injection of psychostimulants. The acute locomotor response to cocaine was normal in mice pretreated with the CB1-R inverse agonist $N$-(piperidin-1-yl)-5-(4-iodophenyl)-1-(2,4-dichlorophenyl)-4-methyl-1H-pyrazole-3-carboxamide (AM251), whereas no sensitization was observed in response to a second administration a week later. Locomotor responses to cocaine and D-amphetamine were decreased in CB1-R-deficient mice, and sensitization was impaired. To determine how CB1-R controls long-lasting effects of psychostimulants, we studied cocaine-activated signaling pathways. Cocaine-induced cAMP-dependent phosphorylation of glutamate receptor 1 was altered in the striatum of CB1-R mutant mice but not of AM251-treated mice. In contrast, cocaine-induced phosphorylation of extracellular signal-regulated kinase (ERK) was blocked in both CB1-R mutant and antagonist-pretreated mice. Conditional deletion of $\mathrm{CB} 1-\mathrm{R}$ in forebrain principal neurons or GABAergic neurons prevented cocaine-induced ERK activation in dorsal striatum and nucleus accumbens. Our results provide strong evidence for the role of the endocannabinoid system in regulating neuronal circuits critical for long-lasting effects of cocaine, presumably by acting on CB1-R located on terminals of striatal medium spiny neurons.
\end{abstract}

Key words: cocaine; sensitization; extracellular signal-regulated kinase; endocannabinoids; striatum; GluR1; DARPP-32; AM251; rimonabant; conditional knock-out

\section{Introduction}

Drugs of abuse have the common ability to increase extracellular dopamine (DA) in the nucleus accumbens (NAcc) (Di Chiara and Imperato, 1988). They are thought to mimic the effects of naturally reinforcing stimuli and to distort the normal role of DA neurons in coding reward prediction errors and regulating the plasticity of corticostriatal transmission (Berke and Hyman, 2000; Everitt and Wolf, 2002; Reynolds and Wickens, 2002; Schultz, 2002; Kelley, 2004). A single exposure to cocaine or other drugs of abuse induces long-lasting effects on electrophysiological and behavioral responses, revealing their powerful ability to control brain plasticity (Vanderschuren et al., 1999; Ungless et al., 2001; Faleiro et al., 2003; Saal et al., 2003; Fourgeaud et al., 2004;

\footnotetext{
Received Sept. 11, 2006; revised May 19, 2007; accepted May 19, 2007.

This work was supported by Inserm and by grants from Action Concertée Incitative Physiologie et Développement and Agence Nationale pour la Recherche ANR-05-NEUR-020-03 (J.-A.G.). A.-G.C. was supported by a scholarship from Ecole de I'Inserm. We thank Dr. P. Greengard, P. Lombroso, and A. Nairn for providing antibodies; $G$ Schütz, J. Rubenstein, and M. Ekker for providing the Cre-expressing mouse lines; and K. Monory for helping in the mouse colony and genotyping of mice.

${ }^{*}$ A. -G.C. and E.V. contributed equally to this work.

Correspondence should be addressed to Jean-Antoine Girault, Inserm U839, Institut du Fer à Moulin, 17 rue du Fer à Moulin, 75005 Paris, France. E-mail: jean-antoine.girault@fer-a-moulin.inserm.fr.

G. Marsicano's present address: Inserm, Avenir, Institut François Magendie, F-33076 Bordeaux, France. DOI:10.1523/JNEUROSCI.3936-06.2007

Copyright $\odot 2007$ Society for Neuroscience $\quad 0270-6474 / 07 / 276937-11 \$ 15.00 / 0$
}

Valjent et al., 2005). These persistent alterations participate in the complex modifications that lead to addiction and linked to craving and relapse (Robinson and Berridge, 1993; Berke and Hyman, 2000).

Several lines of evidence suggest that the endocannabinoid system is an important component of the reward mechanisms. Endocannabinoids are retrograde messengers that regulate a variety of brain functions through stimulation of cannabinoid receptor 1 (CB1-R), a receptor highly enriched in the basal ganglia (Herkenham et al., 1991; Tsou et al., 1998; Marsicano and Lutz, 1999). CB1-R is expressed in GABAergic medium-size spiny neurons (MSNs) and interneurons and is mostly localized in axon terminals and preterminals of these neurons (Matsuda et al., 1993; Marsicano and Lutz, 1999; Hohmann and Herkenham, 2000; Kofalvi et al., 2005; Matyas et al., 2006). CB1-R is also expressed in glutamatergic terminals in the NAcc (Robbe et al., 2001) and, presumably, in corticostriatal projecting neurons (Monory et al., 2006; Uchigashima et al., 2007).

Endocannabinoids play an important role in the modulation of synaptic plasticity in dorsal striatum and NAcc [for review, see Freund et al. (2003), Gerdeman and Lovinger (2003), and Piomelli (2003)]. Moreover, dopamine agonists and psychostimulants increase the striatal release of endocannabinoids, suggesting that they could participate in the effects of psychostimulant drugs 
(Giuffrida et al., 1999; Patel et al., 2003; Centonze et al., 2004). However, although the endocannabinoid system is clearly involved in the behavioral effects of drugs of abuse [for review, see De Vries and Schoffelmeer (2005) and Maldonado et al. (2006)], its precise role is not fully elucidated.

Here, we investigated the role of CB1-R in acute and longlasting behavioral effects of a single injection of psychostimulants. We examined its role in cocaine-activated signaling pathways. We focused on the extracellular signal-regulated kinase (ERK) pathway, which is regulated by cannabinoids in various models (Wartmann et al., 1995; Bouaboula et al., 1997; Valjent et al., 2001; Derkinderen et al., 2003) and which plays a critical role in long-lasting effects of drugs of abuse (Valjent et al., 2000, 2005; Girault et al., 2006; Lu et al., 2006). Using genetic and pharmacological approaches, we found that activation of CB1-R regulates the locomotor sensitization induced by a single drug administration. We also demonstrated an important contribution of CB1-R in the activation of ERK pathway in MSNs in response to psychostimulants.

\section{Materials and Methods}

Animals. Male 8-week-old C57BL/6J mice were purchased from Charles River (L'Arbresle, France). Male (2-3 months of age) wild-type and CB1R-null mice were generated as described previously (Ledent et al., 1999) and backcrossed for 15 generations to a CD1 background. Experimental animals were generated by crossing wild-type or mutant littermates and matched for age and weight. Male (2-5 months of age) conditional CB1-R mutant mice were littermates and generated in a predominant C57BL/6N background (backcrossed for five generations) as described previously (Marsicano et al., 2003; Monory et al., 2006). All mice were kept at least 1 week in the animal house in stable conditions of temperature $\left(22^{\circ} \mathrm{C}\right)$ and humidity $(60 \%)$ with a constant cycle of $12 \mathrm{~h}$ light and $12 \mathrm{~h}$ dark and ad libitum access to food and water. During the $3 \mathrm{~d}$ preceding the Western blotting experiments, mice were habituated to injections by daily intraperitoneal saline administration. Pharmacological treatments were performed with drugs or vehicle, and, when indicated, the CB1-R inverse agonists $N$-(piperidin-1-yl)-5-(4-iodophenyl)-1-(2,4dichlorophenyl)-4-methyl-1 $\mathrm{H}$-pyrazole-3-carboxamide (AM251) and rimonabant were injected $15 \mathrm{~min}$ before. Animal care was conducted in accordance with the standard ethical guidelines (National Institutes of Health publication number 85-23, revised 1985; European Community Guidelines on the Care and Use of Laboratory Animals; and French Agriculture and Forestry Ministry guidelines for handling animals, decree 87849, license A 75-05-22) and approved by the local ethical committee.

Drugs. (+)- $\alpha$-Methylphenethylamine [D-amphetamine (D-amph)] sulfate salt and cocaine-HCl were from Sigma-Aldrich (St. Quentin Fallavier, France). Drugs were dissolved in $0.9 \%$ (w/v) $\mathrm{NaCl}$ (saline) and injected intraperitoneally. AM251 was from Tocris (Biotrend, Köln, Germany) and dissolved in $0.9 \%(\mathrm{w} / \mathrm{v}) \mathrm{NaCl}$ and $0.1 \%(\mathrm{v} / \mathrm{v})$ Tween 20 (Sigma-Aldrich). Rimonabant (SR141716A) was from SanofiSynthelabo (Montpellier, France) and dissolved in a solution of $10 \%$ ethanol, $10 \%$ cremophor EL in distilled water $(\mathrm{v} / \mathrm{v})$.

Immunoblotting. At the indicated times after treatment, mice were decapitated, and their heads were immediately frozen in liquid nitrogen $(12 \mathrm{~s})$. When the animals were pretreated with inverse agonists $15 \mathrm{~min}$ before cocaine, they were killed $10 \mathrm{~min}$ after the cocaine injection. The frozen heads were cut into $210-\mu \mathrm{m}$-thick slices with a cryostat, and 10 frozen microdisks ( $1.4 \mathrm{~mm}$ diameter) were punched out bilaterally from the dorsal striatum and stored at $-80^{\circ} \mathrm{C}$. Micropunches were homogenized by the addition of a hot solution (maintained in a boiling water bath) of $1 \%(\mathrm{w} / \mathrm{v})$ SDS and $1 \mathrm{~mm}$ sodium orthovanadate in water, immediate sonication, and incubation at $100^{\circ} \mathrm{C}$ for $5 \mathrm{~min}$ to inactivate phosphatases and proteases. Equal amounts of protein $(100 \mu \mathrm{g})$ were separated by SDS-PAGE ( $10 \%$ acrylamide, w/v) before electrophoretic transfer onto a nitrocellulose membrane (Hybond Pure; GE Healthcare, Orsay, France). Membranes were blocked for $1 \mathrm{~h}$ at room temperature in Tris-buffered saline (TBS) (100 mm NaCl and $10 \mathrm{~mm}$ Tris, $\mathrm{pH} 7.5)$ with
$0.05 \%(\mathrm{v} / \mathrm{v})$ Tween 20 for detection of phospho-ERK1/2 or 5\% (w/v) nonfat dry milk for phospho-glutamate receptor subunit 1 (GluR1), respectively. Membranes were then incubated overnight at $4^{\circ} \mathrm{C}$ with primary antibodies. Bound antibodies were detected with horseradish peroxidase-conjugated anti-rabbit or anti-mouse antibodies (diluted 1:4000; GE Healthcare) and visualized by enhanced chemiluminescent detection (GE Healthcare). The same membranes were probed for proteins independently of their phosphorylation state after stripping of antibodies in a buffer containing $100 \mathrm{~mm}$ glycine, pH 2.5, $200 \mathrm{~mm} \mathrm{NaCl}$, $0.1 \%(\mathrm{v} / \mathrm{v})$ Tween 20 , and $0.1 \%(\mathrm{v} / \mathrm{v}) \beta$-mercaptoethanol for $45 \mathrm{~min}$ at room temperature, followed by extensive washing in TBS and incubation in blocking buffer. The relevant immunoreactive bands were quantified by laser-scanning densitometry using Scion (Frederick, MD) Image software. For evaluating effects on protein phosphorylation, the ratio of signals obtained with phospho-specific antibodies and antibodies reacting independently of the phosphorylation state of the protein (total) was determined for each sample. The results normalized for each blot were expressed as percentages of saline-treated controls. The following antibodies were used for immunoblotting: dopamine- and cAMP-regulated phosphoprotein, $M_{\mathrm{r}}=32,000$ (DARPP-32; mouse monoclonal antibodies C24-5.a/6.a; 1:10,000) and phospho-Thr-34-DARPP-32 (rabbit antibodies CC500; 1:500), ERK1/2 (rabbit antibodies; 1:1000; Millipore, Mundolsheim, France), diphospho-Thr183-Tyr185-ERK1/2 (P-ERK; monoclonal antibody; 1:1000; Promega, Charbonnière, France), $\alpha$ subunit of the heterotrimeric G-protein $\mathrm{G}_{\text {olf }}\left(\mathrm{G} \alpha_{\text {olf }}\right.$; rabbit antibodies; 1:1000), GluR1 (rabbit antibodies; 1:500; Millipore), phospho-Ser-845GluR1 (rabbit antibodies; 1:500, Millipore), regulator of $\mathrm{Ca}^{2+}$ signaling (RCS; mouse monoclonal antibody 204; 1:5000), striatal-enriched protein tyrosine phosphatase (STEP; mouse monoclonal antibody, 23E5; 1:2000), and tyrosine hydroxylase (mouse monoclonal antibodies; 1:4000; AbCys, Paris, France). Antibodies for DARPP-32, phosphoDARPP-32, and RCS were gifts from Prof. Paul Greengard (The Rockefeller University, New York, NY), and antibody for STEP was a gift from Prof. Paul Lombroso (Yale University, New Haven, CT). Antibodies against $\mathrm{G} \alpha_{\text {olf }}$ were as described previously (Herve et al., 2001).

Immunohistofluorescence of brain sections. Procedures were as described previously (Valjent et al., 2000, 2005). In brief, mice were rapidly anesthetized by intraperitoneal injection of pentobarbital $(50 \mathrm{mg} / \mathrm{kg}$; Sanofi-Aventis, Paris, France) before intracardiac perfusion of $4 \%(\mathrm{w} / \mathrm{v})$ paraformaldehyde in $0.1 \mathrm{M} \mathrm{Na}_{2} \mathrm{HPO}_{4} / \mathrm{NaH}_{2} \mathrm{PO}_{4}$ buffer, $\mathrm{pH} 7.5$, delivered with a peristaltic pump at $20 \mathrm{ml} / \mathrm{min}$ during $5 \mathrm{~min}$. Brains were postfixed and cut with a vibratome (Leica, Rueil-Malmaison, France), and sections $(30 \mu \mathrm{m})$ were kept in a solution containing 30\% ethylene glycol, $30 \%$ glycerol, and $0.1 \mathrm{M}$ phosphate buffer at $-20^{\circ} \mathrm{C}$ until they were processed for immunofluorescence as described previously (Valjent et al., 2000, 2005). After $\mathrm{H}_{2} \mathrm{O}_{2}$ treatment and permeabilization, free-floating sections were incubated with rabbit antibodies for diphospho-ERK (phosphoThr202-Tyr204-ERK1/2, cat-9101; dilution 1:400; Cell Signaling Technology, Beverly, MA) overnight at $4^{\circ} \mathrm{C}$. After three rinses in TBS, sections were incubated for $2 \mathrm{~h}$ at room temperature with the secondary fluorescent antibody (1:400; Cy3-coupled anti-IgG; Invitrogen, Cergy Pontoise, France) in TBS. Sections were then rinsed three times in TBS and mounted on a slide under coverslips using Vectashield (Vector Laboratories, AbCys, Paris, France).

Images of the sections were acquired with fluorescence microscope (Leica) using MetaMorph software. Anatomical regions were identified according to the atlas of Paxinos and Franklin (2001). P-ERKimmunoreactive neurons were considered positive when the fluorescence intensity in their nucleus was superior to a fixed threshold. On each section, cells were counted in each hemisphere in four fields of dorsal striatum, two fields in the shell and one in the core of the NAcc, and values were added up to obtain the number of P-ERK-positive cells in each region of the striatum in a given section. The values in the two hemispheres were averaged and used as data points for the section.

In situ hybridization. Single and double in situ hybridization were performed as described previously (Marsicano and Lutz, 1999; Marsicano et al., 2003) using riboprobes against mouse CB1-R and GAD65 (Marsicano and Lutz, 1999).

Behavioral analysis. Locomotor activity was measured in a circular 
corridor with four infrared beams placed at every $90^{\circ}$ (Imetronic, Pessac, France) in a low-luminosity environment. Counts were incremented by consecutive interruption of two adjacent beams (i.e., mice moving through one-quarter of the circular corridor). Mice were habituated for $30 \mathrm{~min}$ in the locomotor box during 3 consecutive days before the actual experiments were performed and were placed in the corridor $30 \mathrm{~min}$ before injection for the acute experiments. The protocol used to evaluate the long-lasting effects of a single injection of drug on locomotor sensitization induced by cocaine was initially described in rats (Vanderschuren et al., 1999) and adapted to mice (Valjent et al., 2005). After $3 \mathrm{~d}$ of habituation to saline injections, mice received a single injection of drug (20 mg/kg cocaine or $2 \mathrm{mg} / \mathrm{kg}$ D-amphetamine) (acute response) on day 4 and were challenged with a test injection of cocaine or D-amphetamine at the same dose 1 week later (sensitized response).

Statistical analysis. Behavioral, biochemical, and immunofluorescence studies were analyzed by two-way ANOVA followed by Bonferroni's test. Locomotor sensitization studies were analyzed by two-way ANOVA with matching data (i.e., comparing the response of each mouse to the first and second drug injections). Results are expressed as means \pm SEM, and the $p$ threshold for significance was 0.05 . Statistical analysis was performed with Prism 3.0 software (GraphPad Software, San Diego, CA).

\section{Results}

\section{Pharmacological blockade of CB1-R alters locomotor sensitization by cocaine}

We first examined the consequences of the acute blockade of CB1-R with the specific inverse agonist AM251 (Gatley et al., 1996). Vehicle or AM251 (3 or $10 \mathrm{mg} / \mathrm{kg}$ ) was injected $15 \mathrm{~min}$ before the first or the second injection of cocaine a week later, to determine the contribution of CB1-R in the induction or the expression of behavioral sensitization (Fig. 1). AM251 at doses that block completely CB1-R (Shearman et al., 2003) did not modify the hyperactivity induced by a single injection of cocaine: $10 \mathrm{mg} / \mathrm{kg}$ cocaine in mice pretreated with vehicle, $550 \pm 80$ quarter turns per $60 \mathrm{~min}$, or AM $251(3 \mathrm{mg} / \mathrm{kg}), 501 \pm 68$ quarter turns per $60 \mathrm{~min} ; 20 \mathrm{mg} / \mathrm{kg}$ cocaine in mice pretreated with vehicle, $870 \pm 32$ quarter turns per $60 \mathrm{~min}$, or AM251 $(3 \mathrm{mg} / \mathrm{kg}), 828 \pm$ 102 quarter turns per $60 \mathrm{~min} ; 20 \mathrm{mg} / \mathrm{kg}$ cocaine in mice pretreated with vehicle, $884 \pm 67$ quarter turns per $60 \mathrm{~min}$, or AM251 (10 mg/kg), $826 \pm 150$ quarter turns per $60 \mathrm{~min}$ (Fig. $1 A-C$, left and middle). As reported previously (Valjent et al., 2005, 2006), a clear sensitization of cocaine locomotor effects was found when vehicle-pretreated mice received a second injection of cocaine (10 or $20 \mathrm{mg} / \mathrm{kg}$ ) (Fig. $1 \mathrm{~A}-\mathrm{C}$, left). In contrast, in mice pretreated with AM251 (3 or $10 \mathrm{mg} / \mathrm{kg}$ ) before the first cocaine injection, the sensitization to the second cocaine injection was virtually abolished (Fig. $1 A-C$, middle). However, AM251 (3 or $10 \mathrm{mg} / \mathrm{kg}$ ) pretreatment given before the second injection failed to block the behavioral sensitization (Fig. $1 A-C$, right). Thus, the use of a systemically injected CB1-R inverse agonist shows that $\mathrm{CB} 1-\mathrm{R}$ plays a role in the induction but not in the expression of cocaine-induced locomotor sensitization.

\section{Acute locomotor effects of psychostimulant drugs and sensitization are altered in CB1-R mutant mice}

We then tested the effects of cocaine in mutant mice lacking CB1-R. Acute administration of cocaine (Fig. 2A) or D-amphetamine (Fig. $2 B$ ) induced a dose-dependent hyperlocomotion in both wild-type and CB1-R-deficient mice. However, although mice of both genotypes had identical locomotor responses at $10 \mathrm{mg} / \mathrm{kg}$ cocaine, CB1-R-null mice responded significantly less to higher doses of cocaine ( 20 and $30 \mathrm{mg} / \mathrm{kg}$ ) and to all of the tested doses of D-amphetamine ( 2 and $4 \mathrm{mg} / \mathrm{kg}$ ). Cocaine and D-amphetamine increase extracellular levels of monoamines, including dopamine, and CB1-R has been reported to control negatively the responses to stimulation of dopamine $\mathrm{D}_{2}$ receptors $\left(D_{2}-R s\right)$ (Giuffrida et al., 1999). Because the results with psychostimulants appeared to be contradictory with this previous report, we analyzed the locomotor effects of dopaminergic $D_{1}$ and $\mathrm{D}_{2}$ agonists (supplemental Fig. 1, available at www.jneurosci.org as supplemental material). The hyperlocomotion induced by $\mathrm{D}_{1}-\mathrm{R}$ agonist chloro-PB was similar in both genotypes, whereas a high dose $(20 \mathrm{mg} / \mathrm{kg})$ of quinpirole induced a hyperlocomotion specifically in mutant mice (supplemental Fig. 1, available at www. jneurosci.org as supplemental material), in agreement with the data in rats showing that the blockade of CB1-R increased the effects of the $\mathrm{D}_{2}$ agonist (Giuffrida et al., 1999). Therefore, our results suggested that the alteration of psychostimulant locomotor effects in CB1-R mutant mice did not result from a specific impairment of its $\mathrm{D}_{1}$ or $\mathrm{D}_{2}$ component.

We then tested the response of CB1-R mutant mice to a second injection of psychostimulant (Fig. 2C-F). A significant increase in the response to the second injection was observed in response to cocaine $(20 \mathrm{mg} / \mathrm{kg}$ ) (Fig. $2 \mathrm{C}$ ) but not to D-amph (2 $\mathrm{mg} / \mathrm{kg}$ ) (Fig. 2E). When sensitization was expressed as a ratio of the response to the second injection to the response to the first, it was clear that the variability was much higher in mutant than in wildtype mice, as shown by the significant difference in variances (Fig. $2 E, F)$. Thus, sensitization to psychostimulants appeared altered in CB1-R mutant mice. Study of paired values for individual mice and of the distribution of ratios shows that in the absence of CB1-R, sensitization occurred in some mice but not in others, whereas the response was very consistent in wild-type mice.

\section{Cocaine-activated phosphorylation pathways are altered in the dorsal striatum of CB1-R-null mice}

To investigate the molecular alterations that may account for the impaired locomotor responses and the differences between AM251-treated and CB1-R mutant mice, we investigated the signaling pathways activated by cocaine in these two models. Cocaine activates multiple signal transduction pathways in the striatum and other brain regions, which are thought to mediate some of its acute and delayed effects (Valjent et al., 2000, 2006; Nestler, 2001; Svenningsson et al., 2005). We first examined the basal levels of proteins involved in striatal signaling in the striatum of CB1-R-null mice (Table 1), as well as adenylyl cyclase activity (data not shown). None of these parameters differed between wild-type and CB1-R-deficient mice. We then investigated the functional activation of these pathways in response to cocaine $(20$ $\mathrm{mg} / \mathrm{kg}$ ), by immunoblotting of brain samples obtained by rapid freezing, a procedure that prevents uncontrolled postmortem dephosphorylation (see Materials and Methods). We examined the phosphorylation of a well characterized cAMP-dependent protein kinase (PKA) substrate, GluR1 Ser-845, which is phosphorylated in response to cocaine administration, leading to an increased conductance of AMPA receptors (Roche et al., 1996; Snyder et al., 2000). In wild-type mice, cocaine stimulated phosphorylation of GluR1 Ser-845 in the dorsal striatum (Fig. 3A). In CB1-R-null mice, a slight nonsignificant increase in basal Ser-845 phosphorylation was observed, but no significant effect of cocaine was detected (Fig. 3A). The phosphorylation state of Ser845 depends directly on the action of PKA and indirectly on the inhibition of protein phosphatase-1 by DARPP-32 phosphorylated on Thr-34 by PKA (Snyder et al., 2000). We therefore examined DARPP-32 phosphorylation on Thr-34 in response to cocaine in wild-type and CB1-R-null mice. As described previously (Snyder et al., 2000), cocaine administration induced phosphorylation of DARPP-32 on Thr-34 in wild-type mice (Fig. 3B). 


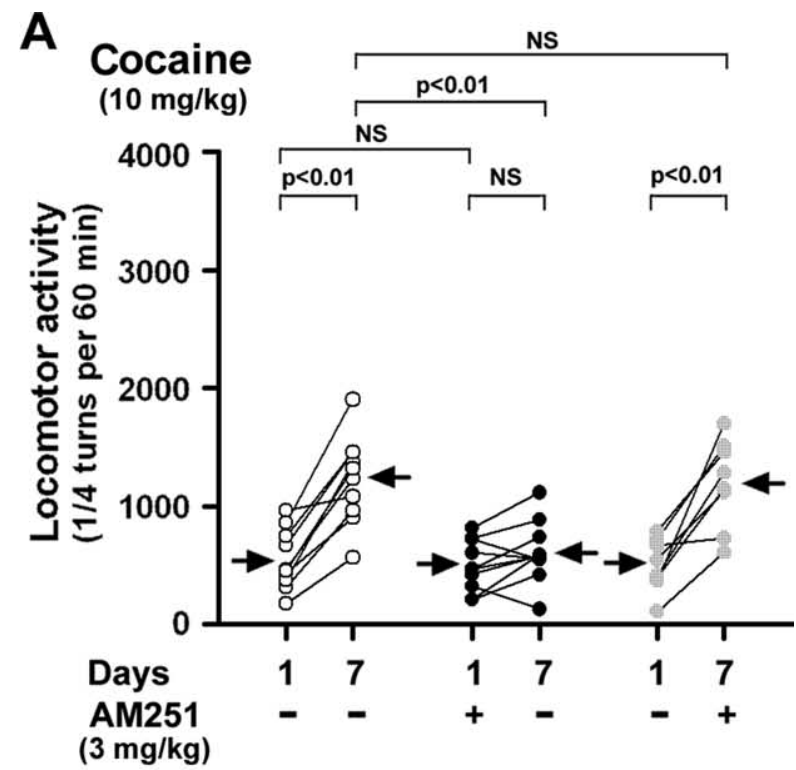

B

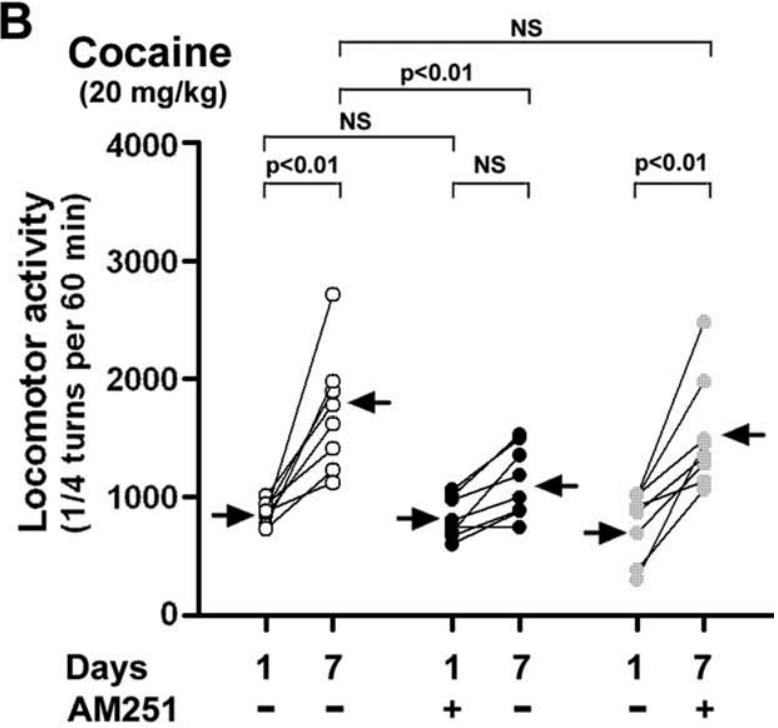

( $3 \mathrm{mg} / \mathrm{kg}$ )

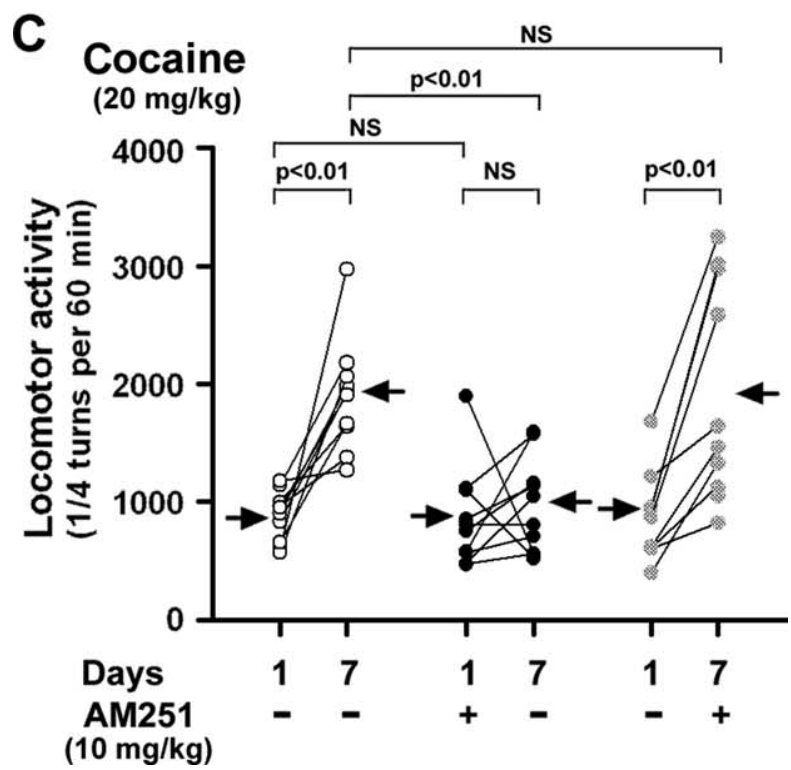

In CB1-R-deficient mice, the basal phosphorylation of DARPP-32 appeared increased, albeit not significantly, but no further change was observed in response to cocaine (Fig. $3 B$ ). These results revealed an alteration of the PKA pathway activation in response to cocaine in CB1-R-null mice.

We then examined the activation of ERK1/2, a protein kinase critical for the induction of long-term effects of cocaine (Valjent et al., 2000, 2005). We used the immunoreactivity for the doubly phosphorylated (phospho-Thr-202/Tyr-204 in human ERK1) forms of ERK1 and ERK2 as an index of their activation. As expected, an increase in the phosphorylation of the two ERK isoforms, largely predominant on ERK2, was observed in response to cocaine administration in wild-type mice (Fig. $3 C$ ). In contrast, in CB1-R-null mice, ERK2 activation in response to cocaine was virtually abolished in the dorsal striatum (Fig. 3C). Altogether, these results indicate a profound alteration of the striatal $\mathrm{D}_{1}$-activated phosphorylation pathways in CB1-R-null mice.

Cocaine-induced ERK phosphorylation and c-Fos induction are blocked in the dorsal striatum and nucleus accumbens of CB1-R-null mice

To obtain more detailed anatomical information on the functional role of CB1-R in ERK activation in the striatum, we studied the distribution of the doubly phosphorylated form of ERK1/2 using immunofluorescence (Fig. 4A,B). Phosphorylation of ERK1/2 induced by cocaine $(20 \mathrm{mg} / \mathrm{kg})$ was prevented in the dorsal striatum, as well as in the NAcc core and shell of CB1-R mutant mice (Fig. 4A,B). Similar results were obtained using D-amph (5 mg/kg) (supplemental Fig. 2, available at www.jneurosci.org as supplemental material).

To determine whether CB1-R was also necessary for the transcriptional effects of cocaine, we analyzed the expression of $c$-fos, an immediate early gene induced in the dorsal striatum and in the NAcc through an ERK-mediated pathway (Graybiel et al., 1990; Moratalla et al., 1993; Valjent et al., 2000). The expression of $c$-fos was studied by measuring the immunoreactivity for the c-Fos protein (Fig. 4C). In wild-type mice, a strong induction of $c$-fos was observed in the dorsal striatum, and a similar trend was found in the NAcc (Fig. 4C,D). In contrast, cocaine-induced c-Fos expression was blocked in CB1-R-null mice (Fig. 4C,D). Altogether, these results indicate that $\mathrm{CB} 1-\mathrm{R}$ is essential for biochemical

Figure 1. AM251, a CB1-R inverse agonist, does not alter acute locomotor effects but prevents locomotor sensitization induced by a single injection of cocaine. Mice received a cocaine injection $[10(\boldsymbol{A})$ or $20(\boldsymbol{B}, \boldsymbol{C}) \mathrm{mg} / \mathrm{kg}$, i.p.] on days 1 and 7 . Fifteen minutes before cocaine administration, mice were pretreated with vehicle or with $\operatorname{AM} 251[3(\boldsymbol{A}, \boldsymbol{B})$ or $10(\boldsymbol{C}) \mathrm{mg} / \mathrm{kg}$, i.p.] on day 1 (middle) or day 7 (right). Data for each mouse are shown individually. Arrows indicate the mean locomotor activity for each group ( $n=8-11$ mice per group). Statistical analysis was done with two-way repeated-measures ANOVA for matching data. Induction of behavioral sensitization: $\boldsymbol{A}$, interaction between days and AM251 pretreatment $\left(F_{(1,18)}=26.38 ; p<\right.$ 0.01); effect of days $\left(F_{(1,18)}=52.78 ; p<0.01\right)$; effect of $\operatorname{AM} 251\left(F_{(1,18)}=8.50 ; p<0.01\right) ; \boldsymbol{B}$, interaction between days and AM251 pretreatment $\left(F_{(1,14)}=7.80 ; p<0.05\right)$; effect of days $\left(F_{(1,14)}=36.18 ; p<0.01\right)$; effect of AM251 $\left(F_{(1,14)}=6.64 ; p<0.05\right)$; $C$, interaction between days and AM251 pretreatment $\left(F_{(1,18)}=10.36 ; p<0.01\right)$; effect of days $\left(F_{(1,18)}=15.54 ; p<\right.$ $0.01)$; effect of $\operatorname{AM} 251\left(F_{(1,18)}=20.70 ; p<0.01\right)$. Expression of behavioral sensitization: $A$, interaction between days and AM251 pretreatment $\left[F_{(1,14)}=0.03\right.$; not significant (NS)]; effect of days $\left(F_{(1,14)}=87.11 ; p<0.01\right)$; effect of AM251 $\left(F_{(1,14)}=2.59 ; N S\right) ; \boldsymbol{B}$, interaction between days and AM251 pretreatment $\left(F_{(1,14)}=0.2 ; \mathrm{NS}\right)$; effect of days $\left(F_{(1,14)}=48.07 ; p<0.01\right)$; effect of AM251 $\left(F_{(1,14)}=0.87 ; \mathrm{NS}\right) ; C$, interaction between days and AM251 pretreatment $\left(F_{(1,18)}=0.01 ; \mathrm{NS}\right)$; effect of days $\left(F_{(1,18)}=46.38 ; p<0.01\right)$; effect of AM251 $\left(F_{(1,18)}=0.00\right.$; NS). Post hoc comparisons were done with Bonferroni's posttest; $p$ values for comparisons between the first and second injection are indicated on the figure for each group. 
A

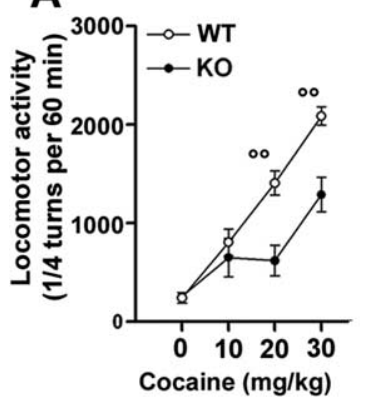

B

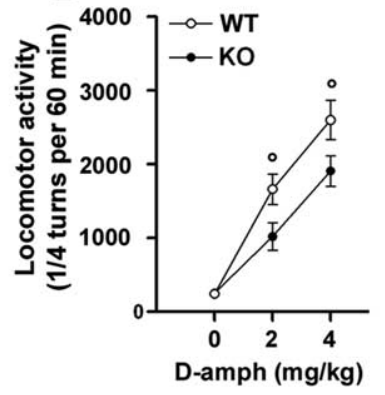

$p<0.01$

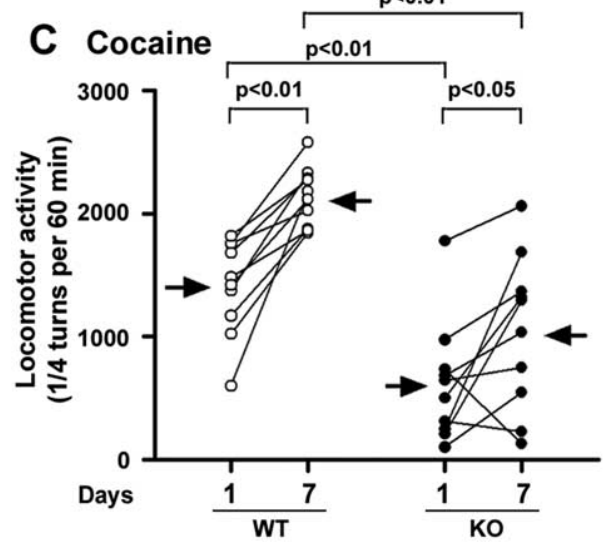

D
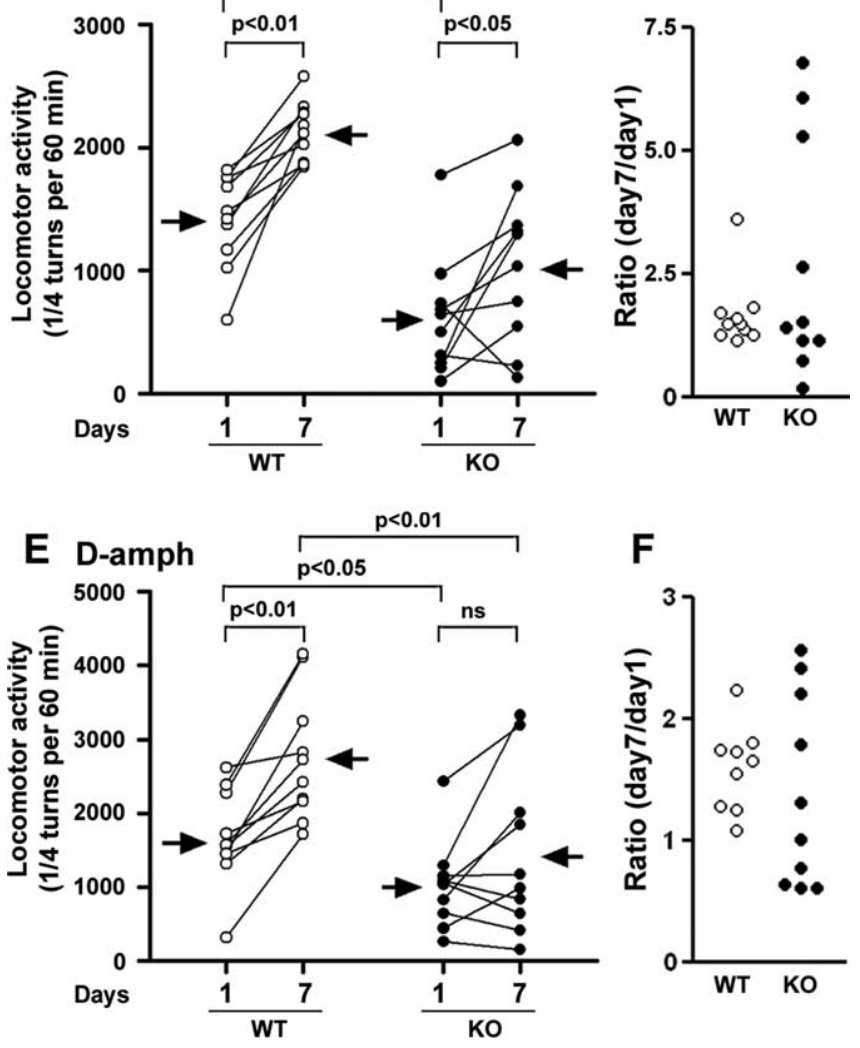

$\mathbf{F}$

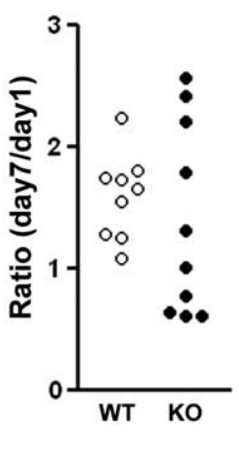

Figure 2. Acute and sensitized locomotor responses induced by psychostimulant drugs are altered in CB1-R mutant mice. $\boldsymbol{A}, \boldsymbol{B}$, Locomotor responses to an injection of cocaine $(10,20$, and $30 \mathrm{mg} / \mathrm{kg}$, i.p.; $\boldsymbol{A}$ ) or D-amph (2 and $4 \mathrm{mg} / \mathrm{kg}$, i.p.; $\boldsymbol{B}$ ) in wild-type (WT) and (B1-R-null (K0) mice. Data (means $\pm \mathrm{SEM} ; n=10-11$ mice per group) were compared using two-way ANOVA analysis: interaction between genotype and dose of cocaine $\left(F_{(3,64)}=5.49 ; p<0.01\right)$; effect of dose $\left(F_{(3,64)}=44.57 ; p<0.01\right)$; effect of genotype $\left(F_{(1,64)}=23.02 ; p<0.01\right)$; interaction between genotype and dose of D-amphetamine $\left[F_{(2,50)}=2.58\right.$; not significant (ns) $]$; effect of dose $\left(F_{(2,50)}=67.27 ; p<0.01\right)$; effect of genotype $\left(F_{(1,50)}=9.74 ; p<0.01\right)$. Bonferroni's posttest: ${ }^{\circ} p<0.05,{ }^{\circ} p<0.01$ compared with wild type. $C$, Comparison of the locomotor effects of a first injection of cocaine $(20 \mathrm{mg} / \mathrm{kg})$ and of a second injection $7 \mathrm{~d}$ later. Data for each mouse are shown individually. The position of the mean is indicated by an arrow for each group. Statistical analysis was done with two-way repeated-measures ANOVA: interaction between genotype and days $\left(F_{(1,18)}=1.97 ;\right.$ NS); effect of days $\left(F_{(1,18)}=27.91 ; p<0.01\right)$; effect of genotype $\left(F_{(1,18)}=29.55 ; p<0.01\right)$. Post hoc comparisons were done with Bonferroni's posttest. Comparison between genotypes: day 1 WT versus KO ( $p<0.01)$; day 7 WT versus K0 $(p<0.01)$. D, Ratios: cocaine-induced locomotor activity at day $7 /$ locomotor activity at day 1. Variances were significantly different (Bartlett test, $p<0.03$ ). $\boldsymbol{E}$, Same as in $\boldsymbol{C}$ except that D-amphetamine $(2 \mathrm{mg} / \mathrm{kg})$ was used instead of cocaine. Two-way repeatedmeasures ANOVA: interaction between genotype and days $\left(F_{(1,18)}=4.15\right.$; NS); effect of days $\left(F_{(1,18)}=23.20 ; p<0.01\right)$; effect of genotype $\left(F_{(1,18)}=8.16 ; p<0.05\right)$. Post hoc comparisons were done with Bonferroni's posttest. Comparison between genotypes: day 1 WT versus K0 ( $p<0.05)$; day 7 WT versus K0 $(p<0.01)$. $\boldsymbol{F}$, Ratios as in $\boldsymbol{D}$. The variances were different (Bartlett test, $p<0.001$ ).
Table 1. Levels of proteins important for signal transduction in the dorsal striatum of wild-type (WT) and CB1-R-deficient (CB1-R K0) mice

\begin{tabular}{llll}
\hline & WT & CB1-R K0 & \\
\hline TH & $100 \pm 9$ & $107 \pm 8$ & NS \\
ERK1 & $100 \pm 3$ & $102 \pm 5$ & NS \\
ERK2 & $100 \pm 3$ & $104 \pm 3$ & NS \\
GluR1 & $100 \pm 4$ & $107 \pm 6$ & NS \\
DARPP-32 & $100 \pm 8$ & $107 \pm 8$ & NS \\
RCS & $100 \pm 13$ & $111 \pm 9$ & NS \\
STEP46 & $100 \pm 8$ & $130 \pm 10$ & NS \\
STEP61 & $100 \pm 10$ & $115 \pm 28$ & NS \\
G $\alpha_{\text {olf }}$ & $100 \pm 5$ & $103 \pm 4$ & NS \\
\hline
\end{tabular}

Protein levels were normalized to the average of wild-type samples and expressed as a percentage of this average value (means \pm SEM; $n=6$ ). TH, Tyrosine hydroxylase; STEP61 and STEP46, striatal-enriched protein tyrosine phosphatase, $M_{\mathrm{r}}=61,000$ and 46,000 , respectively; NS, not significant. Statistical analysis was done by Student's $t$ test. No significant difference was observed.

A
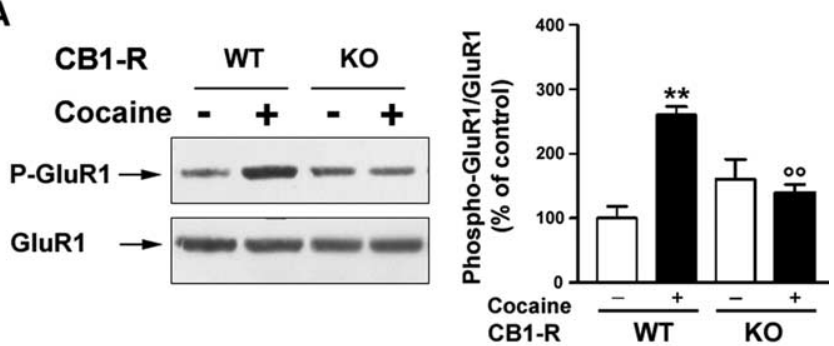

B
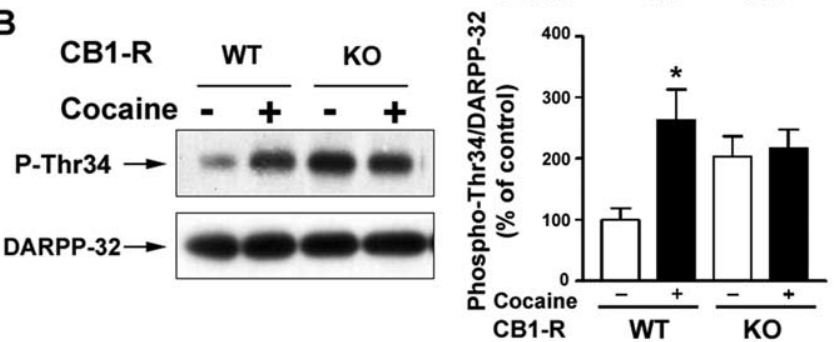

C
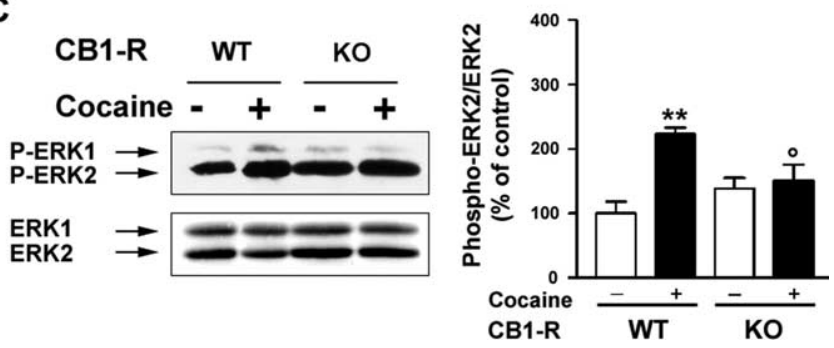

Figure 3. Effects of cocaine on protein phosphorylation in the dorsal striatum of CB1-Rdeficient mice. Wild-type (WT) and CB1-R-null (KO) mice were injected with $20 \mathrm{mg} / \mathrm{kg}$ saline $(-)$ or cocaine $(+)$ and killed 10 min later. Their heads were rapidly frozen, and the striata were dissected without thawing. $\boldsymbol{A}$, Immunoblot analysis of phosphorylation of GluR1 at Ser-845 (P-GluR1; top) and total GluR1 (bottom). Immunoreactive bands were quantified by laser scanning, and results were expressed as ratios of phosphorylated/total protein and normalized to the mean of saline-treated wild-type mice (percentage of control). Data (means \pm SEM; $n=$ 7-9 mice per group) were analyzed using two-way ANOVA: interaction between genotype and treatment $\left(F_{(1,32)}=20.28 ; p<0.01\right)$; effect of treatment $\left(F_{(1,32)}=12.27 ; p<0.01\right)$; effect of genotype $\left[F_{(1,32)}=2.25\right.$; not significant (NS) $]$. B, Same as in $A$ except that the proteins analyzed were phospho-Thr-34-DARPP-32 (P-Thr34; top) and total DARPP-32 (bottom). Data (means \pm $\mathrm{SEM} ; n=6$ mice per group) were analyzed using two-way ANOVA: interaction between genotype and treatment $\left(F_{(1,18)}=4.51 ; p<0.05\right)$; effect of treatment $\left(F_{(1,18)}=6.23 ; p<0.05\right)$; effect of genotype $\left(F_{(1,18)}=0.66 ; \mathrm{NS}\right)$. C, Same as in $\boldsymbol{A}$ except that the proteins analyzed were P-ERK1/2 (top) and total ERK1 and ERK2 (bottom). Note that P-ERK1 was barely detectable in most experiments. Data (means $\pm \mathrm{SEM} ; n=7-9$ mice per group) were analyzed using two-way ANOVA: interaction between genotype and treatment $\left(F_{(1,28)}=9.78 ; p<0.01\right)$; effect of treatment $\left(F_{(1,28)}=14.95 ; p<0.01\right)$; effect of genotype $\left(F_{(1,28)}=0.93 ; \mathrm{NS}\right)$. Bonferroni's posttest, ${ }^{*} p<0.05,{ }^{* *} p<0.01$ compared with saline; ${ }^{\circ} p<0.05,{ }^{\circ 0} p<$ 0.01 compared with WT. 
responses to cocaine that have been shown previously to be highly correlated with longlasting behavioral effects.

Pharmacological blockade of CB1-R prevents cocaine-induced phosphorylation of ERK

We examined the phosphorylation of GluR1 in response to cocaine $(20 \mathrm{mg} / \mathrm{kg})$ in mice in which CB1-R was acutely blocked by AM251. In contrast to the results obtained in mutant mice, pretreatment with AM251 (10 mg/kg) did not alter basal or cocaine-induced phosphorylation of GluR1 in the striatum (Fig. 5A). These results indicate that acute pharmacological blockade of CB1-R was less disruptive to PKA signaling than genetic deletion of these receptors.

We then examined the ERK pathway. Immunoblotting showed that pretreatment with AM251 (10 mg/kg) increased the basal phosphorylation of ERK1 and ERK2 in the dorsal striatum (Fig. 5B). Cocaine administration $(20 \mathrm{mg} / \mathrm{kg}) 15 \mathrm{~min}$ after AM251 failed to further alter ERK phosphorylation (Fig. 5B). We studied further the effects of this CB1-R inverse agonist by measuring $\mathrm{P}$-ERK1/2 immunofluorescence in various regions of the striatum (Fig. 6). Pretreatment with AM251 by itself did not change the number of P-ERK-positive cell bodies in the dorsal striatum or in the NAcc shell and core (Fig. 6A). In contrast, AM251 pretreatment blocked ERK phosphorylation in response to cocaine (Fig. 6A). The same results were obtained using rimonabant ( 3 $\mathrm{mg} / \mathrm{kg}$ ), another widely used CB1-R inverse agonist (Fig. 6B). It is interesting to note that the intrinsic effect of AM251 on basal ERK phosphorylation apparent by immunoblotting was not detected by immunofluorescence. This discrepancy may be attributable to the fact that immunofluorescence detects only the cells in which a strong activation of ERK takes place. It is likely that AM251 induced a diffuse activation of ERK that did not reach a local concentration sufficient for detection by immunofluorescence. However, it is important to emphasize that the two methods gave convergent results concerning the lack of effect of cocaine in mice treated with a CB1-R inverse agonist.

Cell type-specific study of the role of the CB1-R in cocaine-induced ERK activation

We first examined whether endogenously released endocannabinoids acting on CB1-R contributed to the activation of ERK by psychostimulants. CB1-Rs were
A

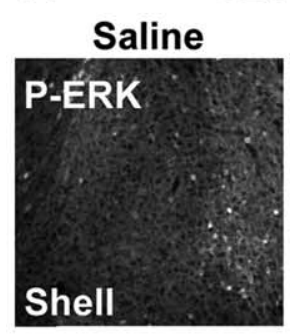

CB1-R WT
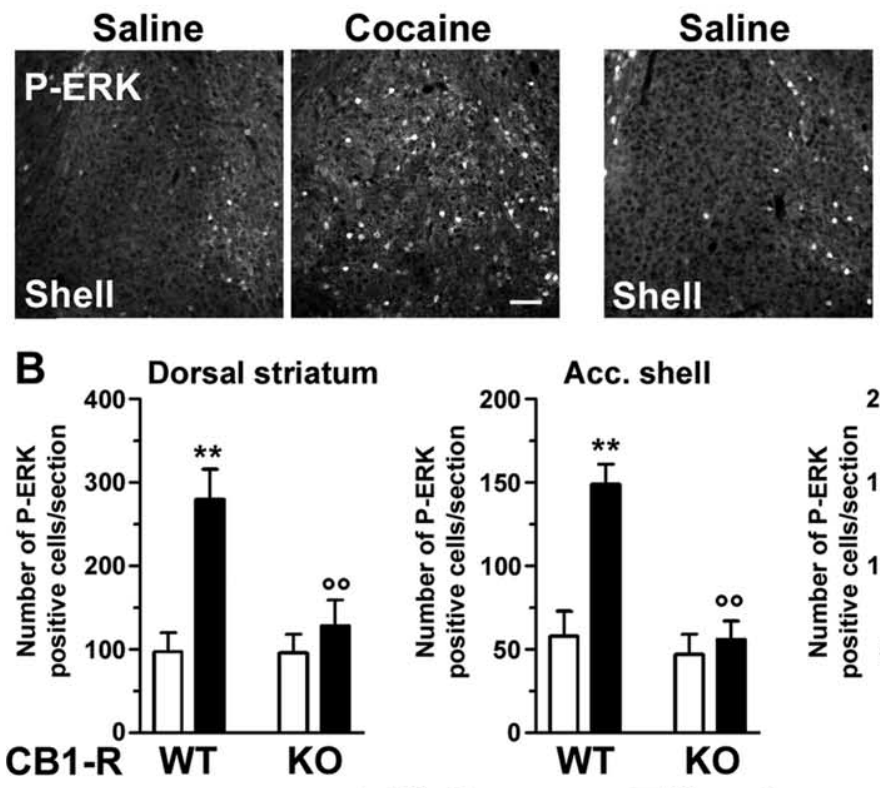

CB1-R KO
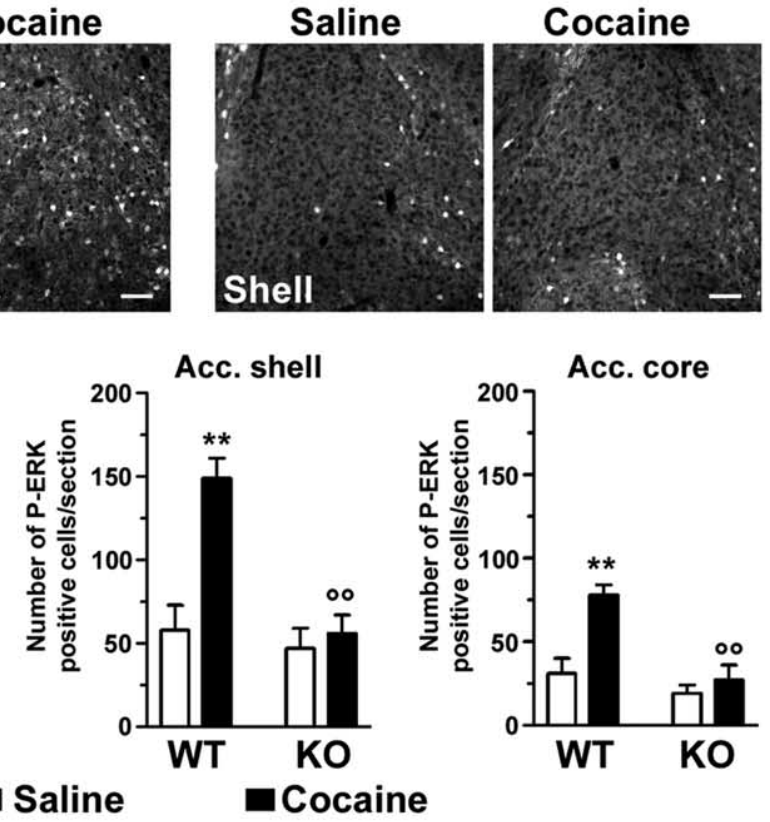

C

CB1-R WT
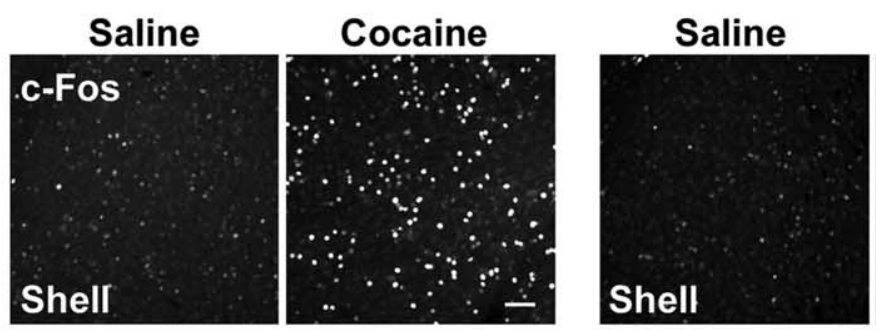

CB1-R KO
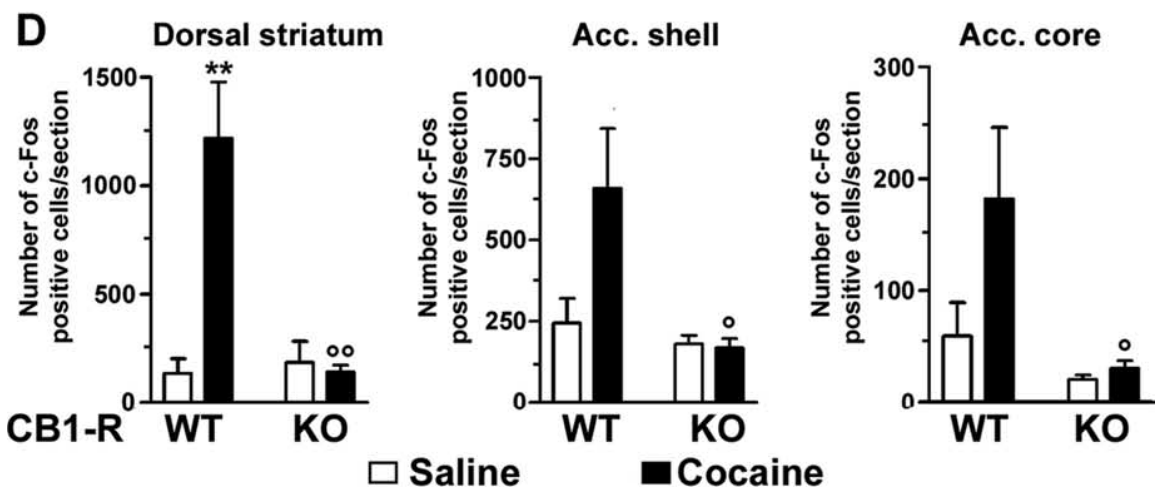

Figure 4. Cocaine-induced ERK phosphorylation and c-Fos induction in the dorsal striatum and nucleus accumbens in CB1-Rnull mice. $A$, P-ERK immunostaining in the shell of the NAcc in wild-type (WT) and CB1-R-null (KO) mice 10 min after the injection of saline or cocaine $(20 \mathrm{mg} / \mathrm{kg})$, as indicated. Scale bars, $50 \mu \mathrm{m}$. B, Quantification of P-ERK-positive cells in sections of the dorsal striatum and nucleus accumbens shell (Acc. shell) and core (Acc. core). Data (means \pm SEM; $n=8-10$ per group) were analyzed using two-way ANOVA: dorsal striatum, interaction between treatment and genotype $\left(F_{(1,30)}=6.67 ; p<0.05\right)$; effect of treatment $\left(F_{(1,30)}=13.53 ; p<0.01\right)$; effect of genotype $\left(F_{(1,30)}=6.85 ; p<0.05\right)$. Acc. shell, interaction between treatment and genotype $\left(F_{(1,30)}=10.72 ; p<0.01\right)$; effect of treatment $\left(F_{(1,30)}=17.24 ; p<0.01\right)$; effect of genotype $\left(F_{(1,30)}=15.94 ; p<\right.$ $0.01)$. Acc. core, interaction between treatment and genotype $\left(F_{(1,30)}=6.30 ; p<0.05\right)$; effect of treatment $\left(F_{(1,30)}=16.45 ; p<\right.$ 0.01); effect of genotype $\left(F_{(1,30)}=12.53 ; p<0.01\right)$. C, c-Fos immunostaining in the shell of the NAcc in WT and KO mice 90 min after the injection of saline or cocaine $(20 \mathrm{mg} / \mathrm{kg})$, as indicated. Scale bars, $50 \mu \mathrm{m}$. D, Quantification of c-Fos-positive cells in sections of the dorsal striatum, Acc. shell, and Acc. core. Data (means \pm SEM; $n=4$ per group) were analyzed using two-way ANOVA: dorsal striatum, interaction between treatment and genotype $\left(F_{(1,12)}=15.39 ; p<0.01\right)$; effect of treatment $\left(F_{(1,12)}=13.04 ; p<0.01\right)$; effect of genotype $\left(F_{(1,12)}=12.74 ; p<0.01\right)$. Acc. shell, interaction between treatment and genotype $\left(F_{(1,12)}=4.4 ; p=0.057\right)$; effect of treatment $\left[F_{(1,12)}=3.92\right.$; not significant $\left.(\mathrm{NS})\right]$; effect of genotype $\left(F_{(1,12)}=7.45 ; p<0.05\right)$. Acc. core, interaction between treatment and genotype $\left(F_{(1,12)}=2.52\right.$; NS); effect of treatment $\left(F_{(1,12)}=3.5 ; \mathrm{NS}\right)$; effect of genotype $\left(F_{(1,12)}=7.21 ; p<0.05\right)$. Bonferroni's posttest, ${ }^{* *} p<0.01$ compared with saline; ${ }^{\circ} p<0.05,{ }^{\circ} p<0.01$ compared with WT. 
A

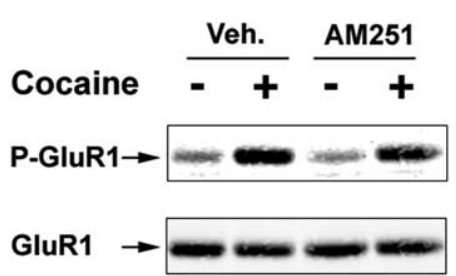

B

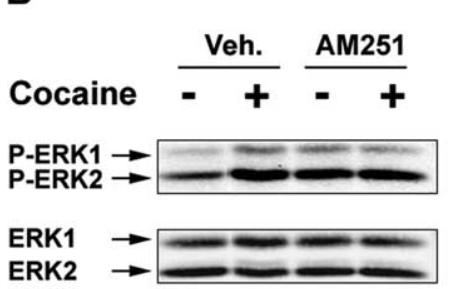

Figure 5. Effects of the CB1-R inverse agonist AM251 on cocaine-induced phosphorylation of ERK and GluR1 in the mouse striatum. Mice were pretreated with vehicle (Veh.) or AM251 (10 $\mathrm{mg} / \mathrm{kg}$, i.p.) $15 \mathrm{~min}$ before the injection of $20 \mathrm{mg} / \mathrm{kg}$ saline (-) or cocaine (+) and killed $10 \mathrm{~min}$ later. Their heads were rapidly frozen, and the striata were dissected without thawing. $\boldsymbol{A}$, Immunoblot analysis of phosphorylation of GluR1 at Ser-845 (P-GluR1; top) and total GluR1 (bottom). Immunoreactive bands were quantified by laser scanning, and results were expressed as ratios of phosphorylated protein to total protein and normalized to the mean of saline-treated wild-type mice (percentage of control). Data (means \pm SEM; $n=7-9$ mice per group) were analyzed using two-way ANOVA: interaction between cocaine and AM251 treatment $\left[F_{(1,33)}=0.62\right.$; not significant (NS)]; effect of cocaine $\left(F_{(1,33)}=64.02 ; p<0.01\right)$; effect of AM251 treatment $\left(F_{(1,33)}=1.66 ; \mathrm{NS}\right)$. $\boldsymbol{B}$, Same as in $\boldsymbol{A}$ except that the proteins analyzed were P-ERK1/2 (top) and total ERK1 and ERK2 (bottom). Note that P-ERK1 was barely detectable in most experiments. Data (means $\pm \mathrm{SEM} ; n=8-9$ mice per group) were analyzed using twoway ANOVA: interaction between cocaine and AM251 treatment $\left(F_{(1,35)}=4.13 ; p<0.05\right)$; effect of cocaine $\left(F_{(1,35)}=17.37 ; p<0.01\right)$; effect of AM251 treatment $\left(F_{(1,35)}=3.16 ; \mathrm{NS}\right)$. Bonferroni's posttest, ${ }^{* *} p<0.01$ compared with saline; ${ }^{\circ} p<0.05$ compared with vehicle.

not necessary for the activation of ERK by dopamine and glutamate (a combination mimicking the action of cocaine) in striatal neurons in culture (supplemental Fig. 3, available at www.jneurosci.org as supplemental material). These results showed that dopamine and glutamate were able to activate the ERK pathway independently of CB1-R in a simplified model that lacks the circuit organization present in vivo. It is thus likely that endocannabinoids play a modulatory role at the circuit level.

We examined more precisely the role of CB1-R at the circuit level in vivo, by testing in which neuronal population(s) CB1-R is critical for cocaine-induced ERK activation in striatal MSNs. We used conditional mouse mutant lines, obtained by crossing mice with a CB1-R coding region flanked by lox $\mathrm{P}$ sequences $\left(\mathrm{CB1}{ }^{\mathrm{f} / \mathrm{f}}\right)$, and mice expressing the Cre recombinase under the control of cell type-specific promoters (Marsicano et al., 2003; Monory et al., 2006). We first analyzed ERK activation in $\mathrm{CB}_{1}{ }^{\mathrm{f} / \mathrm{f}}$ mice, also expressing Cre under the control of calcium/calmodulindependent protein kinase II $\alpha(\mathrm{CaMKII} \alpha)$ regulatory sequences $\left(\mathrm{CB} 1^{\mathrm{f} / \mathrm{f} \text {; } a M K I I} \alpha-\mathrm{Cre}\right)$, which lack CB1-R expression from forebrain principal neurons (Marsicano et al., 2003). In situ hybridization showed a dramatic decrease in the expression of CB1-R transcripts in the cortex of these mice, which was present only in some scattered, intensely expressing cells, and a virtually complete absence of signal in the striatum (Fig. 7A). At higher magnification, double labeling for CB1-R and GAD65 mRNAs revealed that residual $\mathrm{CB} 1-\mathrm{R}$ expression in the cortex was confined to
GABAergic interneurons (Fig. 7B) (Marsicano et al., 2003). We tested the effects of a single cocaine injection on the activation of ERK phosphorylation in CB1 ${ }^{\mathrm{f} / \mathrm{f} \text {;CaMKII } \alpha \text {-Cre }}$ mice (Fig. $7 C, D$ ). The cocaine-induced increase observed in the dorsal striatum and NAcc shell and core of wild-type mice was profoundly reduced in conditional mutant mice (Fig. $7 C, D$ ). These results revealed that the CB1-R located in forebrain principal neurons, including cortical glutamatergic neurons and/or MSNs, was necessary for the activation of ERK by cocaine.

Principal neurons affected by the mutation in $\mathrm{CB} 1^{\mathrm{f} / \mathrm{F} \mathrm{CaMKII} \alpha-\mathrm{Cre}}$ include both GABAergic striatal MSNs and glutamatergic corticostriatal neurons. To distinguish between $\mathrm{CB} 1-\mathrm{R}$ located in these two classes of neurons, we used $\mathrm{CB} 1^{\mathrm{f} / \mathrm{f} \text { Dlx } 5 / 6 \text {-Cre }}$ mice, a mouse line lacking CB1-R expression from all forebrain GABAergic neurons, because of the expression of Cre under the control of Dlx5/6 regulatory sequences (Monory et al., 2006). In these mice, CB1-R transcripts were not detected in the striatum but were diffusely present in the cerebral cortex (Figs. $7 A, B$ ). The intensely scattered labeled neurons observed in wild-type mice were absent from the cortex, and no colocalization of CB1-R mRNA and GAD65 was observed, attesting to the disappearance of CB1-R from GABAergic neurons (Fig. $7 A, B$ ) (Monory et al., 2006). In these mice, no significant ERK activation was detected in the dorsal striatum and NAcc core and shell in response to cocaine administration (Fig. 7C,D). Because CB1-Rs were absent from GABAergic MSNs in both conditional mutant lines, the most parsimonious explanation of our results is that CB1-Rs in MSNs are critical for ERK activation by cocaine in vivo.

\section{Discussion}

The present study comparing the effects of complete or conditional genetic inactivation of CB1-Rs and their pharmacological blockade allowed circumscribing the specific role of this receptor in the responses to psychostimulants. In agreement with previous reports (Martin et al., 2000; Houchi et al., 2005), we found that endocannabinoids play only a minor role in the hyperlocomotion induced by psychostimulants. Although hyperlocomotion was decreased in CB1-R-deficient mice, it was not modified by acute blockade of CB1-R with AM251 (this study) or rimonabant (Poncelet et al., 1999). In contrast, the present study revealed a role of the endocannabinoid system in cocaine-induced sensitization. We used a protocol that has the advantage to evaluate the enduring consequences of a single administration of cocaine or D-amphetamine without the additional adaptations observed after repeated drug exposure. Using this paradigm, we found an impairment of locomotor sensitization in CB1-R-deficient mice and in AM251-treated mice. This deficit was not detected in studies that used the standard protocol of repeated injections of cocaine in CB1-R-null (Martin et al., 2000) or rimonabant-treated mice (Lesscher et al., 2005), although close examination of the data in these previous reports discloses some changes in the sensitized responses to cocaine. In fact, our study reveals that genetic blockade of CB1-R does not completely prevent sensitization to psychostimulants, but reduces it and makes it more variable. Thus, the endocannabinoid system appears to play an important modulatory role that increases the "reliability" of sensitization, perhaps by facilitating plasticity at a circuit level (see below). The relevance of these observations for drug addiction is speculative, because the role of locomotor sensitization in addiction is disputed. However, sensitization may share some mechanisms with craving and drug seeking (Robinson and Berridge, 2003), in which the endocannabinoid system plays a major role (De Vries et al., 2005). 
The second important conclusion of this work concerns the role of CB1-R in cocaine-activated intracellular signaling pathways. The lack of Ser-845 phosphorylation of GluR1 in CB1-R mutant mice correlated with the decreased locomotor effects of cocaine. Conversely, cocaineinduced phosphorylation of GluR1 and locomotor response were normal in AM251-treated mice. These observations suggest that increased phosphorylation of Ser-845 may contribute to the acute locomotor response to cocaine, in agreement with its role in increasing AMPA receptor currents (Roche et al., 1996; Banke et al., 2000). We observed differences between the absence of CB1-Rs and their acute pharmacological blockade, because altered cAMP-dependent phosphorylation of GluR1 and DARPP-32 and decreased locomotor effects of psychostimulants were present in mutant mice but not in AM251-treated mice. Such differences may reflect a role of CB1-R during development (Galve-Roperh et al., 2006) and its consequences in the adult. Alternatively, they could be the consequence of prolonged lack of CB1-R function and subsequent adaptations of the PKA pathway. Thus, our study emphasizes the importance of comparing the results obtained with inverse agonists with those in genetic models. Each of these approaches has its own advantages and disadvantages. Specificity of pharmacological tools is always questionable, and variables such as doses and time of drug administration might influence the outcomes of pharmacological experiments. However, genetic models have their own limitations, such as developmental effects, and it is the comparison of the results of the two approaches that allows drawing firm conclusions.

We found profound alterations of cocaine-induced ERK activation in both CB1-R mutant and AM251-treated mice. Pharmacological blockade of ERK1/2 activation by SL327 ( $\alpha$-[amino [(4-aminophenyl)thio]methylene]-2-(trifluoromethyl) benzene acetonitrile) prevented locomotor sensitization induced by a single or repeated injections of cocaine (Valjent et al., 2005, 2006). In contrast, genetic deletion of ERK1 had the opposite effect (Ferguson et al., 2006), identifying ERK2 as the key factor. In agreement with these previous reports, cocaine markedly increased ERK2 phosphorylation in the striatum, whereas this increase was prevented in CB1-R-null and AM251- or rimonabant-treated mice. In the light of the importance of ERK activation for the regulation of gene expression by drugs of abuse and for longlasting behavioral responses (Girault et al., 2006; Lu et al., 2006), the role of CB1-R in its regulation is of great interest.

There are several levels at which CB1-R could be implicated in the regulation of ERK. Activation of ERK by cocaine depends on the concomitant stimulation of DA- $\mathrm{D}_{1}$ and glutamate-NMDA receptors (Valjent et al., 2000, 2005). A first hypothesis would be that $\mathrm{CB} 1-\mathrm{R}$ controls ERK activation by regulating corticostriatal glutamatergic transmission. However, CB1-R stimulation de-
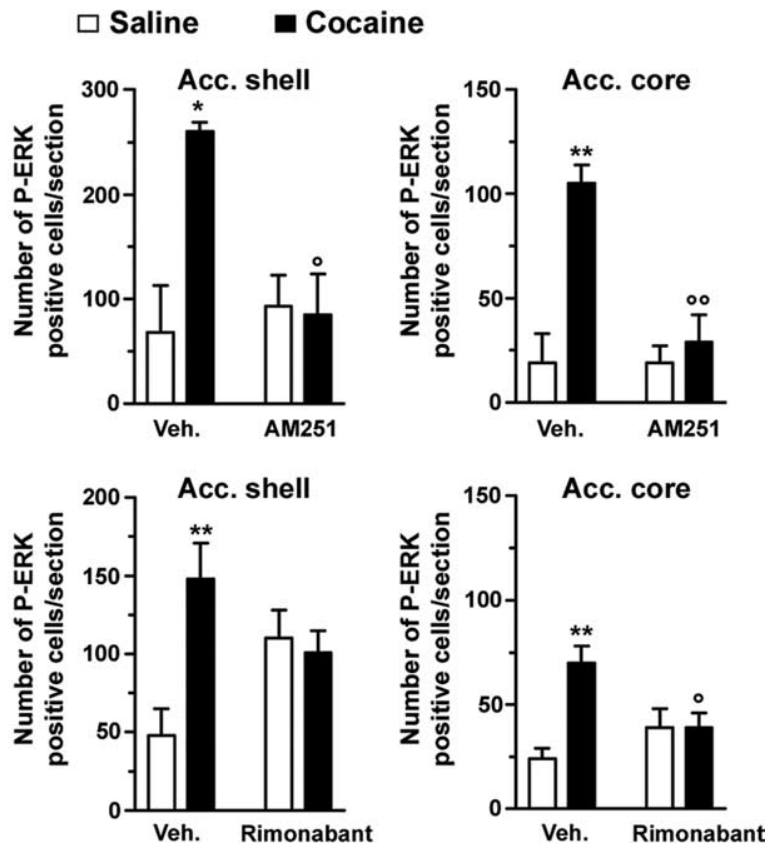

Figure 6. Effects of $C B 1-R$ inverse agonists on cocaine-induced ERK phosphorylation in the dorsal striatum and nucleus accum-

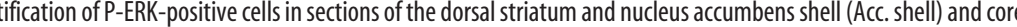

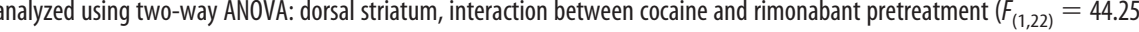
between cocaine and rimonabant pretreatment $\left(F_{(1,22)}=8.34 ; p<0.01\right)$; effect of cocaine $\left(F_{(1,22)}=5.82 ; p<0.01\right)$; effect of effect of cocaine $\left(F_{(1,22)}=8.56 ; p<0.01\right)$; effect of rimonabant $\left(F_{(1,22)}=1.04\right.$; NS). Bonferroni's posttest, ${ }^{*} p<0.05,{ }^{* *} p<0.01$ compared with saline; ${ }^{\circ} p<0.05,{ }^{\circ} p<0.01$ compared with vehicle.

creases glutamate transmission (Hoffman and Lupica, 2001; Huang et al., 2001; Robbe et al., 2001; Pistis et al., 2002; Kofalvi et al., 2005), and the expected effect of CB1-R mutation or inverse agonists would be an increase in ERK phosphorylation. It is thus unlikely that $\mathrm{CB} 1-\mathrm{R}$ regulates ERK phosphorylation in striatal neurons by acting on glutamatergic terminals.

Our results with conditional mutant mice support the role of CB1-R in striatal MSNs. Activation of ERK was prevented in $\mathrm{CB} 1^{\mathrm{f} / \mathrm{f} ; \mathrm{Dlx} 5 / 6-\mathrm{Cre}}$ mice, in which CB1-R was absent from both GABA interneurons and projection neurons, including MSNs. ERK activation was also prevented in $\mathrm{CB} 1^{\mathrm{f} / \mathrm{f} ; \mathrm{CaMKII} \alpha \text {-Cre }}$ mice, in which CB1-R was deleted in principal neurons, including corticostriatal neurons and MSNs. The most parsimonious interpretation of these data is that CB1-R in MSNs plays a central role in the cocaine-induced ERK phosphorylation.

A first hypothesis for the role of CB1-R in MSNs would be that the endocannabinoid system modulates the integration of DAand glutamate-coded signals in these neurons at the postsynaptic level. Although CB1-R stimulation inhibits $\mathrm{D}_{1}$-R-induced formation of cAMP in rat striatum (Bidaut-Russell and Howlett, 1991), concurrent stimulation of CB1-R and $D_{2}-R$ resulted in an increased adenylyl cyclase activity and ERK1/2 phosphorylation (Glass and Felder, 1997; Kearn et al., 2005). Such effects could, in principle, contribute to the role of the endocannabinoid system in ERK phosphorylation in MSNs. The stimulation of CB1-R by 
A

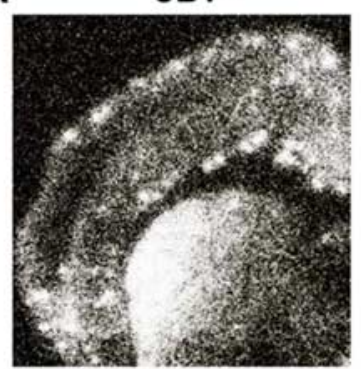

B

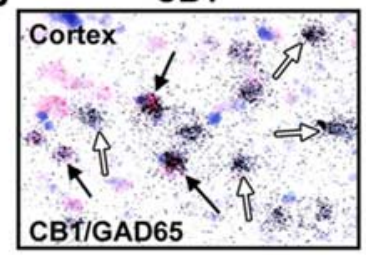

C

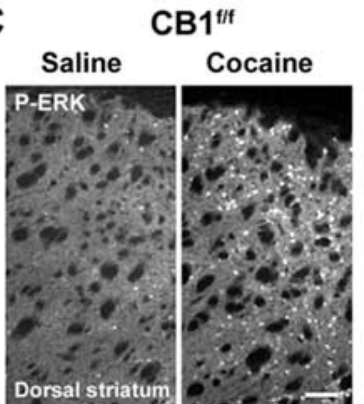

D

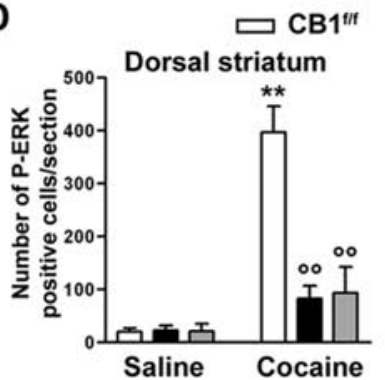

CB1 ${ }^{\text {fff;CaMKIlla-Cre }}$

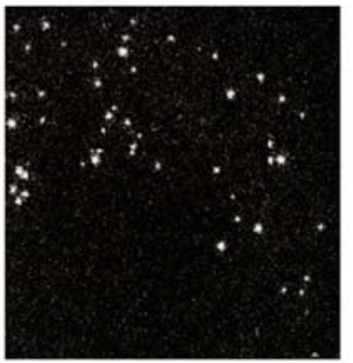

CB1 ${ }^{\text {fff; CaMKKIlla-Cre }}$

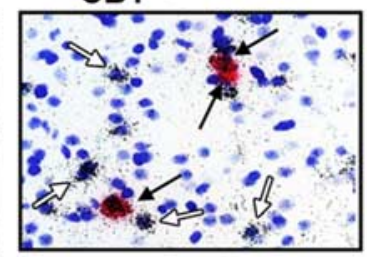

CB1 ${ }^{\text {ffi; CaMKIIla-Cre }}$
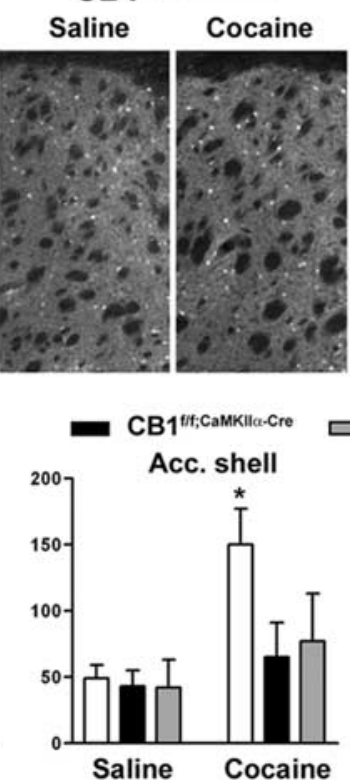

$\mathrm{CB}^{\text {tff; D1 } 1 \times 5 / 6-\mathrm{Cre}}$

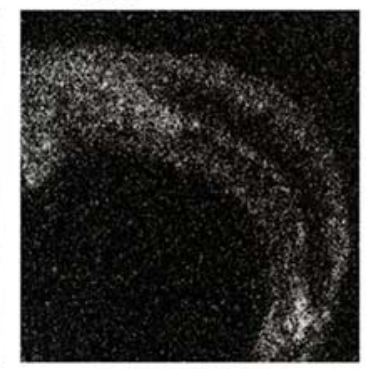

CB1 ${ }^{\text {fff;D1×5/6-Cre }}$

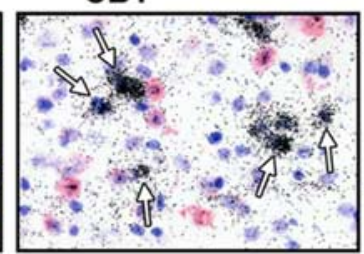

CB1 $1^{\text {ff; } ; 01 \times 5 / 6-C r e}$

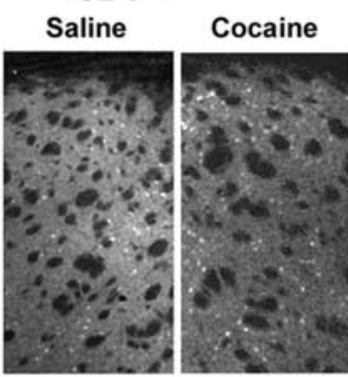

CB1 $1^{\text {fir; Dix } 5 / 6-C r e}$

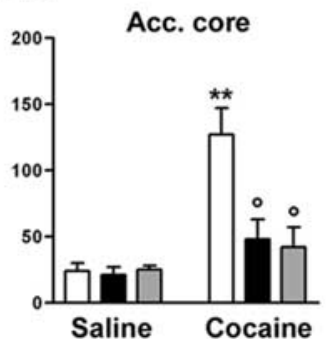

Figure 7. Effects of conditional deletion of $C B 1-R$ in different neuronal subpopulations on cocaine-induced ERK phosphorylation in the striatum. $A$, Micrographs showing $C B 1-R m R N A$ expression in the dorsal striatum and cortex of $C B 1^{\mathrm{f} / \mathrm{f}},\left(\mathrm{CB} 1^{\mathrm{f} / \mathrm{f} ; \mathrm{CaMKKl} \alpha-\mathrm{Cre}}\right.$,

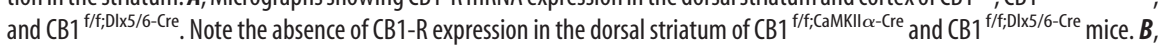
Micrographs showing double in situ hybridization of CB1-R (red staining) together with GAD65 mRNA (silver grains in the cortex of

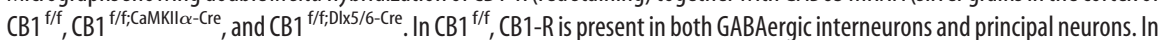
$\mathrm{CB} 1^{\mathrm{f} / \mathrm{f} ; \mathrm{CaMKKI} \alpha-\mathrm{Cre}}, \mathrm{CB} 1-\mathrm{R}$ is only expressed by some GABAergic interneurons, whereas in $\mathrm{CB} 1^{\mathrm{f} / f ; \mathrm{D} / \mathrm{x} 5 / 6-\mathrm{Cre}}, \mathrm{CB} 1-\mathrm{R}$ is only present in glutamatergic neurons. Blue staining corresponds to toluidine blue nuclear staining. Solid arrows, GABAergic interneurons (GAD65 positive) expressing (B1-R mRNA. Open arrows, GABAergic interneurons lacking (B1-R expression. C, P-ERK immunostaining in

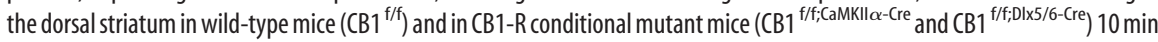
after acute administration of saline or cocaine $(20 \mathrm{mg} / \mathrm{kg})$. Scale bar, $100 \mu \mathrm{m}$. D, Quantification of P-ERK-positive cells in sections of the dorsal striatum and nucleus accumbens shell (Acc. shell) and core (Acc. core) from wild-type (CB1/f/f) and (B1-R conditional mutant $\left(C B 1^{\mathrm{fff} ; \text {; } \mathrm{CaMKIl} \alpha \text {-Cre }}\right.$ and $\left.\mathrm{CB} 1^{\mathrm{f} / f ; \mathrm{D} \times \mathrm{x} 5 / 6 \text {-Cre }}\right)$ mice $10 \mathrm{~min}$ after injection of cocaine $(20 \mathrm{mg} / \mathrm{kg})$. Data (means $\pm \mathrm{SEM} ; n=4-8$ per group) were analyzed using two-way ANOVA: dorsal striatum, interaction between genotypes and treatment $\left(F_{(2,29)}=7.73\right.$; $p<0.01)$; effect of treatment $\left(F_{(1,29)}=20.83 ; p<0.01\right)$; effect of genotypes $\left(F_{(2,29)}=7.53 ; p<0.01\right)$; Acc. shell, interaction between genotypes and treatment $\left[F_{(2,29)}=1.13\right.$; not significant (NS)]; effect of treatment $\left(F_{(1,29)}=5.26 ; p<0.05\right)$; effect of genotypes $\left(F_{(2,29)}=1.56 ; \mathrm{NS}\right)$; Acc. core, interaction between genotypes and treatment $\left(F_{(2,29)}=3.24\right.$; NS); effect of treatment $\left(F_{(1,29)}=10.29 ; p<0.01\right)$; effect of genotype $\left(F_{(2,29)}=3.36 ; p<0.05\right)$. Bonferroni's posttest, ${ }^{*} p<0.05$, ${ }^{* *} p<0.01$ compared with saline; ${ }^{\circ} p<0.05,{ }^{\circ 0} p<0.01$ compared with wild type.

the local release of endocannabinoids could also directly control the ERK pathway, as shown in transfected non-neuronal cell lines (Wartmann et al., 1995; Bouaboula et al., 1997; Derkinderen et al., 2003). However, our results in striatal neurons in primary culture did not support an obligatory role of postsynaptic CB1-R (supplemental Fig. 3 , available at www.jneurosci.org as supplemental material). Accordingly, electron microscopy and electrophysiology failed to reveal CB1-R in the somatodendritic compartment of MSNs (SanudoPena et al., 1999; Julian et al., 2003; Freiman et al., 2006; Matyas et al., 2006), in agreement with their constitutive endocytosis from the plasma membrane in this compartment (Leterrier et al., 2006). In summary, all of the evidence strongly indicates that CB1-R is not involved in the regulation of cocaine-induced phosphorylation of ERK in MSNs at the postsynaptic level.

CB1-R are highly enriched in terminals and preterminal regions of striatal MSNs axons, where they inhibit GABA transmission (Szabo et al., 1998; Hoffman and Lupica, 2001; Manzoni and Bockaert, 2001; Kofalvi et al., 2005; Matyas et al., 2006). Activation of striatal CB1-R on recurrent axon terminals of MSNs leads to presynaptic inhibition of GABAergic transmission (Freiman et al., 2006). Our results suggest that this mechanism may play a role in the control of ERK phosphorylation in response to cocaine in vivo, by facilitating excitation of MSNs as a result of decreased lateral inhibition. CB1-R expressed by MSNs and located in the extrastriatal terminals could also regulate ERK activation by acting at the circuit level. For example, in the substantia nigra pars reticulata, stimulation of CB1-R decreases striatonigral GABAergic transmission (Szabo et al., 2000). If a similar effect exists in striatopallidal terminals of the indirect pathway, stimulation of CB1-R would result in a decreased activity of nigrothalamic neurons and, through multisynaptic circuits (Chevalier and Deniau, 1990), to an increased corticostriatal excitatory transmission. Such a role of CB1-R in the control of the activity of glutamatergic neurons projecting to the striatum is supported by a recent study showing that cocaine-induced glutamate outflow is decreased by AM251 in the striatum of rats previously trained to self-administer $\mathrm{CO}_{-}$ caine (Xi et al., 2006).

Finally, CB1-R in GABAergic terminals that regulate DA neurons could play an important role. Stimulation of CB1-R in vivo increases extracellular DA levels in the striatum (Chen et al., 1990; Tanda et al., 1997). However, blockade or absence of CB1-R is expected to increase the inhibition of DA neurons and thus to decrease DA release in the striatum. In support of this hypothesis, although the cocaine-induced enhancement of extracellular DA measured by microdialysis in the NAcc was unaltered 
in CB1-R-null mice (Soria et al., 2005), a recent study using fastcycling voltammetry shows that blockade of CB1-R attenuates cocaine-induced DA release (Cheer et al., 2007).

In conclusion, our results demonstrate that the endocannabinoid system is required for ERK activation in striatal MSNs. Endocannabinoids are likely to play this role, at the circuit level, by acting on CB1-R located on the terminals of MSNs, either in the striatum or in some of their target regions. This proposed presynaptic control of CB1-R on the output of MSNs provides a basis for the modulatory role of CB1-Rs and their endogenous ligands in the long-lasting effects of psychostimulants. Our results also support the potential interest of CB1-R inverse agonists in the context of addiction.

\section{References}

Banke TG, Bowie D, Lee H, Huganir RL, Schousboe A, Traynelis SF (2000) Control of GluR1 AMPA receptor function by cAMP-dependent protein kinase. J Neurosci 20:89-102.

Berke JD, Hyman SE (2000) Addiction, dopamine, and the molecular mechanisms of memory. Neuron 25:515-532.

Bidaut-Russell M, Howlett AC (1991) Cannabinoid receptor-regulated cyclic AMP accumulation in the rat striatum. J Neurochem 57:1769-1773.

Bouaboula M, Perrachon S, Milligan L, Canat X, Rinaldi-Carmona M, Portier M, Barth F, Calandra B, Pecceu F, Lupker J, Maffrand JP, Le Fur G, Casellas P (1997) A selective inverse agonist for central cannabinoid receptor inhibits mitogen-activated protein kinase activation stimulated by insulin or insulin-like growth factor 1. Evidence for a new model of receptor/ligand interactions. J Biol Chem 272:22330-22339.

Centonze D, Battista N, Rossi S, Mercuri NB, Finazzi-Agro A, Bernardi G, Calabresi P, Maccarrone M (2004) A critical interaction between dopamine D2 receptors and endocannabinoids mediates the effects of cocaine on striatal GABAergic transmission. Neuropsychopharmacology 29:1488-1497.

Cheer JF, Wassum KM, Sombers LA, Heien MLAV, Ariansen JL, Aragona BJ, Phillips PEM, Wightman RM (2007) Phasic dopamine release evoked by abused substances requires cannabinoid receptor activation. J Neurosci 27:791-795.

Chen JP, Paredes W, Li J, Smith D, Lowinson J, Gardner EL (1990) Delta 9-tetrahydrocannabinol produces naloxone-blockable enhancement of presynaptic basal dopamine efflux in nucleus accumbens of conscious, freely-moving rats as measured by intracerebral microdialysis. Psychopharmacology (Berl) 102:156-162.

Chevalier G, Deniau JM (1990) Disinhibition as a basic process in the expression of striatal functions. Trends Neurosci 13:277-280.

Derkinderen P, Valjent E, Toutant M, Corvol JC, Enslen H, Ledent C, Trzaskos J, Caboche J, Girault JA (2003) Regulation of extracellular signalregulated kinase by cannabinoids in hippocampus. J Neurosci 23:2371-2382.

De Vries TJ, Schoffelmeer AN (2005) Cannabinoid CB1 receptors control conditioned drug seeking. Trends Pharmacol Sci 26:420-426.

De Vries TJ, de Vries W, Janssen MC, Schoffelmeer AN (2005) Suppression of conditioned nicotine and sucrose seeking by the cannabinoid-1 receptor antagonist SR141716A. Behav Brain Res 161:164-168.

Di Chiara G, Imperato A (1988) Drugs abused by humans preferentially increase synaptic dopamine concentrations in the mesolimbic system of freely moving rats. Proc Natl Acad Sci USA 85:5274-5278.

Everitt BJ, Wolf ME (2002) Psychomotor stimulant addiction: a neural systems perspective. J Neurosci 22:3312-3320.

Faleiro LJ, Jones S, Kauer JA (2003) Rapid AMPAR/NMDAR response to amphetamine: a detectable increase in AMPAR/NMDAR ratios in the ventral tegmental area is detectable after amphetamine injection. Ann NY Acad Sci 1003:391-394.

Ferguson SM, Fasano S, Yang P, Brambilla R, Robinson TE (2006) Knockout of ERK1 enhances cocaine-evoked immediate early gene expression and behavioral plasticity. Neuropsychopharmacology 31:2660-2668.

Fourgeaud L, Mato S, Bouchet D, Hemar A, Worley PF, Manzoni OJ (2004) A single in vivo exposure to cocaine abolishes endocannabinoid-mediated long-term depression in the nucleus accumbens. J Neurosci 24:6939-6945.

Franklin KBJ, Paxinos G (2001) The mouse brain in stereotaxic coordinates. San Diego: Academic.
Freiman I, Anton A, Monyer H, Urbanski MJ, Szabo B (2006) Analysis of the effects of cannabinoids on identified synaptic connections in the caudate-putamen by paired recordings in transgenic mice. J Physiol 575:789-806.

Freund TF, Katona I, Piomelli D (2003) Role of endogenous cannabinoids in synaptic signaling. Physiol Rev 83:1017-1066.

Galve-Roperh I, Aguado T, Rueda D, Velasco G, Guzman M (2006) Endocannabinoids: a new family of lipid mediators involved in the regulation of neural cell development. Curr Pharm Des 12:2319-2325.

Gatley SJ, Gifford AN, Volkow ND, Lan R, Makriyannis A (1996) 123Ilabeled AM251: a radioiodinated ligand which binds in vivo to mouse brain cannabinoid CB1 receptors. Eur J Pharmacol 307:331-338.

Gerdeman GL, Lovinger DM (2003) Emerging roles for endocannabinoids in long-term synaptic plasticity. Br J Pharmacol 140:781-789.

Girault JA, Valjent E, Caboche J, Herve D (2006) ERK2: a logical AND gate critical for drug-induced plasticity? Curr Opin Pharmacol 7:77-85.

Giuffrida A, Parsons LH, Kerr TM, Rodriguez de Fonseca F, Navarro M, Piomelli D (1999) Dopamine activation of endogenous cannabinoid signaling in dorsal striatum. Nat Neurosci 2:358-363.

Glass M, Felder CC (1997) Concurrent stimulation of cannabinoid CB1 and dopamine D2 receptors augments cAMP accumulation in striatal neurons: evidence for a $G_{s}$ linkage to the $C B 1$ receptor. J Neurosci 17:5327-5333.

Graybiel AM, Moratalla R, Robertson HA (1990) Amphetamine and cocaine induce drug-specific activation of the $\mathrm{c}$-fos gene in striosomematrix compartments and limbic subdivisions of the striatum. Proc Natl Acad Sci USA 87:6912-6916.

Herkenham M, Lynn AB, de Costa BR, Richfield EK (1991) Neuronal localization of cannabinoid receptors in the basal ganglia of the rat. Brain Res 547:267-274.

Herve D, Le Moine C, Corvol JC, Belluscio L, Ledent C, Fienberg AA, Jaber M, Studler JM, Girault JA (2001) G $\alpha_{\text {olf }}$ levels are regulated by receptor usage and control dopamine and adenosine action in the striatum. J Neurosci 21:4390-4399.

Hoffman AF, Lupica CR (2001) Direct actions of cannabinoids on synaptic transmission in the nucleus accumbens: a comparison with opioids. J Neurophysiol 85:72-83.

Hohmann AG, Herkenham M (2000) Localization of cannabinoid CB(1) receptor mRNA in neuronal subpopulations of rat striatum: a doublelabel in situ hybridization study. Synapse 37:71-80.

Houchi H, Babovic D, Pierrefiche O, Ledent C, Daoust M, Naassila M (2005) $\mathrm{CB} 1$ receptor knockout mice display reduced ethanol-induced conditioned place preference and increased striatal dopamine D2 receptors. Neuropsychopharmacology 30:339-349.

Huang CC, Lo SW, Hsu KS (2001) Presynaptic mechanisms underlying cannabinoid inhibition of excitatory synaptic transmission in rat striatal neurons. J Physiol (Lond) 532:731-748.

Julian MD, Martin AB, Cuellar B, Rodriguez De Fonseca F, Navarro M, Moratalla R, Garcia-Segura LM (2003) Neuroanatomical relationship between type 1 cannabinoid receptors and dopaminergic systems in the rat basal ganglia. Neuroscience 119:309-318.

Kearn CS, Blake-Palmer K, Daniel E, Mackie K, Glass M (2005) Concurrent stimulation of cannabinoid CB1 and dopamine D2 receptors enhances heterodimer formation: a mechanism for receptor cross-talk? Mol Pharmacol 67:1697-1704.

Kelley AE (2004) Memory and addiction: shared neural circuitry and molecular mechanisms. Neuron 44:161-179.

Kofalvi A, Rodrigues RJ, Ledent C, Mackie K, Vizi ES, Cunha RA, Sperlagh B (2005) Involvement of cannabinoid receptors in the regulation of neurotransmitter release in the rodent striatum: a combined immunochemical and pharmacological analysis. J Neurosci 25:2874-2884.

Ledent C, Valverde O, Cossu G, Petitet F, Aubert JF, Beslot F, Bohme GA, Imperato A, Pedrazzini T, Roques BP, Vassart G, Fratta W, Parmentier M (1999) Unresponsiveness to cannabinoids and reduced addictive effects of opiates in CB1 receptor knockout mice. Science 283:401-404.

Lesscher HM, Hoogveld E, Burbach JP, van Ree JM, Gerrits MA (2005) Endogenous cannabinoids are not involved in cocaine reinforcement and development of cocaine-induced behavioural sensitization. Eur Neuropsychopharmacol 15:31-37.

Leterrier C, Laine J, Darmon M, Boudin H, Rossier J, Lenkei Z (2006) Constitutive activation drives compartment-selective endocytosis and axonal targeting of type 1 cannabinoid receptors. J Neurosci 26:3141-3153. 
Lu L, Koya E, Zhai H, Hope BT, Shaham Y (2006) Role of ERK in cocaine addiction. Trends Neurosci 29:695-703.

Maldonado R, Valverde O, Berrendero F (2006) Involvement of the endocannabinoid system in drug addiction. Trends Neurosci 29:225-232.

Manzoni OJ, Bockaert J (2001) Cannabinoids inhibit GABAergic synaptic transmission in mice nucleus accumbens. Eur J Pharmacol 412:R3-R5.

Marsicano G, Lutz B (1999) Expression of the cannabinoid receptor CB1 in distinct neuronal subpopulations in the adult mouse forebrain. Eur J Neurosci 11:4213-4225.

Marsicano G, Goodenough S, Monory K, Hermann H, Eder M, Cannich A, Azad SC, Cascio MG, Gutierrez SO, van der Stelt M, Lopez-Rodriguez ML, Casanova E, Schutz G, Zieglgansberger W, Di Marzo V, Behl C, Lutz B (2003) CB1 cannabinoid receptors and on-demand defense against excitotoxicity. Science 302:84-88.

Martin M, Ledent C, Parmentier M, Maldonado R, Valverde O (2000) Cocaine, but not morphine, induces conditioned place preference and sensitization to locomotor responses in CB1 knockout mice. Eur J Neurosci 12:4038-4046.

Matsuda LA, Bonner TI, Lolait SJ (1993) Localization of cannabinoid receptor mRNA in rat brain. J Comp Neurol 327:535-550.

Matyas F, Yanovsky Y, Mackie K, Kelsch W, Misgeld U, Freund TF (2006) Subcellular localization of type 1 cannabinoid receptors in the rat basal ganglia. Neuroscience 137:337-361.

Monory K, Massa F, Egertova M, Eder M, Blaudzun H, Westenbroek R, Kelsch W, Jacob W, Marsch R, Ekker M, Long J, Rubenstein JL, Goebbels S, Nave KA, During M, Klugmann M, Wolfel B, Dodt HU, Zieglgansberger W, Wotjak CT, et al. (2006) The endocannabinoid system controls key epileptogenic circuits in the hippocampus. Neuron 51:455-466.

Moratalla R, Vickers EA, Robertson HA, Cochran BH, Graybiel AM (1993) Coordinate expression of $\mathrm{c}-$ fos and jun $\mathrm{B}$ is induced in the rat striatum by cocaine. J Neurosci 13:423-433.

Nestler EJ (2001) Molecular neurobiology of addiction. Am J Addict 10:201-217.

Patel S, Rademacher DJ, Hillard CJ (2003) Differential regulation of the endocannabinoids anandamide and 2-arachidonylglycerol within the limbic forebrain by dopamine receptor activity. J Pharmacol Exp Ther 306:880-888.

Piomelli D (2003) The molecular logic of endocannabinoid signalling. Nat Rev Neurosci 4:873-884.

Pistis M, Muntoni AL, Pillolla G, Gessa GL (2002) Cannabinoids inhibit excitatory inputs to neurons in the shell of the nucleus accumbens: an in vivo electrophysiological study. Eur J Neurosci 15:1795-1802.

Poncelet M, Barnouin MC, Breliere JC, Le Fur G, Soubrie P (1999) Blockade of cannabinoid (CB1) receptors by 141716 selectively antagonizes druginduced reinstatement of exploratory behaviour in gerbils. Psychopharmacology (Berl) 144:144-150.

Reynolds JN, Wickens JR (2002) Dopamine-dependent plasticity of corticostriatal synapses. Neural Netw 15:507-521.

Robbe D, Alonso G, Duchamp F, Bockaert J, Manzoni OJ (2001) Localization and mechanisms of action of cannabinoid receptors at the glutamatergic synapses of the mouse nucleus accumbens. J Neurosci 21:109-116.

Robinson TE, Berridge KC (1993) The neural basis of drug craving: an incentive-sensitization theory of addiction. Brain Res Brain Res Rev 18:247-291.

Robinson TE, Berridge KC (2003) Addiction. Annu Rev Psychol 54:25-53.

Roche KW, O’Brien RJ, Mammen AL, Bernhardt J, Huganir RL (1996) Characterization of multiple phosphorylation sites on the AMPA receptor GluR1 subunit. Neuron 16:1179-1188.

Saal D, Dong Y, Bonci A, Malenka RC (2003) Drugs of abuse and stress trigger a common synaptic adaptation in dopamine neurons. Neuron $37: 577-582$.
Sanudo-Pena MC, Tsou K, Walker JM (1999) Motor actions of cannabinoids in the basal ganglia output nuclei. Life Sci 65:703-713.

Schultz W (2002) Getting formal with dopamine and reward. Neuron 36:241-263.

Shearman LP, Rosko KM, Fleischer R, Wang J, Xu S, Tong XS, Rocha BA (2003) Antidepressant-like and anorectic effects of the cannabinoid CB1 receptor inverse agonist AM251 in mice. Behav Pharmacol 14:573-582.

Snyder GL, Allen PB, Fienberg AA, Valle CG, Huganir RL, Nairn AC, Greengard P (2000) Regulation of phosphorylation of the GluR1 AMPA receptor in the neostriatum by dopamine and psychostimulants in vivo. J Neurosci 20:4480-4488.

Soria G, Mendizabal V, Tourino C, Robledo P, Ledent C, Parmentier M, Maldonado R, Valverde O (2005) Lack of CB1 cannabinoid receptor impairs cocaine self-administration. Neuropsychopharmacology 30: $1670-1680$

Svenningsson P, Nairn AC, Greengard P (2005) DARPP-32 mediates the actions of multiple drugs of abuse. AAPS J 7:E353-E360.

Szabo B, Dorner L, Pfreundtner C, Norenberg W, Starke K (1998) Inhibition of GABAergic inhibitory postsynaptic currents by cannabinoids in rat corpus striatum. Neuroscience 85:395-403.

Szabo B, Wallmichrath I, Mathonia P, Pfreundtner C (2000) Cannabinoids inhibit excitatory neurotransmission in the substantia nigra pars reticulata. Neuroscience 97:89-97.

Tanda G, Pontieri FE, Di Chiara G (1997) Cannabinoid and heroin activation of mesolimbic dopamine transmission by a common mul opioid receptor mechanism. Science 276:2048-2050.

Tsou K, Brown S, Sanudo-Pena MC, Mackie K, Walker JM (1998) Immunohistochemical distribution of cannabinoid CB1 receptors in the rat central nervous system. Neuroscience 83:393-411.

Uchigashima M, Narushima M, Fukaya M, Katona I, Kano M, Watanabe M (2007) Subcellular arrangement of molecules for 2-arachidonoylglycerol-mediated retrograde signaling and its physiological contribution to synaptic modulation in the striatum. J Neurosci 27:3663-3676.

Ungless MA, Whistler JL, Malenka RC, Bonci A (2001) Single cocaine exposure in vivo induces long-term potentiation in dopamine neurons. Nature 411:583-587.

Valjent E, Corvol JC, Pages C, Besson MJ, Maldonado R, Caboche J (2000) Involvement of the extracellular signal-regulated kinase cascade for cocaine-rewarding properties. J Neurosci 20:8701-8709.

Valjent E, Pages C, Rogard M, Besson MJ, Maldonado R, Caboche J (2001) Delta 9-tetrahydrocannabinol-induced MAPK/ERK and Elk-1 activation in vivo depends on dopaminergic transmission. Eur J Neurosci 14:342-352.

Valjent E, Pascoli V, Svenningsson P, Paul S, Enslen H, Corvol JC, Stipanovich A, Caboche J, Lombroso PJ, Nairn AC, Greengard P, Herve D, Girault JA (2005) Regulation of a protein phosphatase cascade allows convergent dopamine and glutamate signals to activate ERK in the striatum. Proc Natl Acad Sci USA 102:491-496.

Valjent E, Corvol JC, Trzaskos JM, Girault JA, Herve D (2006) Role of the ERK pathway in psychostimulant-induced locomotor sensitization. BMC Neurosci 7:20.

Vanderschuren LJ, Schmidt ED, De Vries TJ, Van Moorsel CA, Tilders FJ, Schoffelmeer AN (1999) A single exposure to amphetamine is sufficient to induce long-term behavioral, neuroendocrine, and neurochemical sensitization in rats. J Neurosci 19:9579-9586.

Wartmann M, Campbell D, Subramanian A, Burstein SH, Davis RJ (1995) The MAP kinase signal transduction pathway is activated by the endogenous cannabinoid anandamide. FEBS Lett 359:133-136.

Xi ZX, Gilbert JG, Peng XQ, Pak AC, Li X, Gardner EL (2006) Cannabinoid CB1 receptor antagonist AM251 inhibits cocaine-primed relapse in rats: role of glutamate in the nucleus accumbens. J Neurosci 26:8531-8536. 